\title{
Altered Histone Monoubiquitylation Mediated by Mutant Huntingtin Induces Transcriptional Dysregulation
}

\author{
Mee-Ohk Kim, Prianka Chawla, Ryan P. Overland, Eva Xia, Ghazaleh Sadri-Vakili, and Jang-Ho J. Cha \\ MassGeneral Institute for Neurodegenerative Disease, Department of Neurology, Massachusetts General Hospital, Charlestown, Massachusetts 02129
}

\begin{abstract}
Although transcriptional dysregulation is a critical pathogenic mechanism in Huntington's disease (HD), it is still not known how mutant huntingtin causes it. Here we show that alteration of histone monoubiquitylation is a key mechanism. Disrupted interaction of huntingtin with Bmi-1, a component of the hPRC1L E3 ubiquitin ligase complex, increases monoubiquityl histone H2A (uH2A) levels in a cell culture model of HD. Genes with expression that is repressed in transgenic R6/2 mouse brain have increased uH2A and decreased uH2B at their promoters, whereas actively transcribed genes show the opposite pattern. Reduction in $\mathrm{uH} 2 \mathrm{~A}$ reverses transcriptional repression and inhibits methylation of histone $\mathrm{H} 3$ at lysine 9 in cell culture. In contrast, reduction in uH2B induces transcriptional repression and inhibits methylation of histone $\mathrm{H} 3$ at lysine 4 . This is the first report to demonstrate hPRC1L as a huntingtin-interacting histone modifying complex and a crucial role for histone monoubiquitylation in mammalian brain gene expression, which broadens our understanding of histone code. These findings also provide a rationale for targeting histone monoubiquitylation for therapy in HD.
\end{abstract}

Key words: histone monoubiquitylation; huntingtin; Bmi-1; histone methylation; transcription; histone code

\section{Introduction}

Huntington's disease (HD) is caused by an expansion of a CAG trinucleotide repeat in the HD gene encoding an abnormally long polyglutamine within huntingtin protein (The Huntington's Disease Collaborative Research Group, 1993). Human HD and transgenic mouse models of HD show downregulation of particular genes including neurotransmitter receptors, second messengers, and calcium homeostasis molecules (Augood et al., 1997; Cha et al., 1998; Luthi-Carter et al., 2000; Hodges et al., 2006). It is probable that mutant huntingtin has its toxic effects by affecting the expression of genes that are important to neural functioning. However, the molecular mechanisms responsible for transcriptional dysregulation have not been defined.

Posttranslational modifications of histones including acetylation, methylation, phosphorylation, ubiquitylation, and SUMOylation appear to be key factors in turning specific genes on or off, which is defined as the "histone code" (Strahl and Allis, 2000; Jason et al., 2002; Shiio and Eisenman, 2003). Among these, histone monoubiquitylation is the least understood modification, occurring in the mostly monoubiquitylated form, mainly on histones H2A and H2B (Goldknopf et al., 1975; West and Bon-

Received Sept. 19, 2007; revised Feb. 4, 2008; accepted Feb. 11, 2008.

This work was supported by grants from the National Institute of Neurological Disorders and Stroke (NS38106, NS45242), the Huntington's Disease Society of America (HDSA) Coalition for the Cure (J.-H.J.C.), the Glendorn Foundation (J.-H.J.C.), the Massachusetts Biomedical Research Corporation (Tosteson Postdoctoral Fellowship to M.-0.K.), and HDSA (research fellowship to M.-0.K.). We thank Dr. Miguel Vidal (Universidad Autonoma de Madrid, Madrid, Spain) and Jaehoon Kim and Dr. Robert Roeder (Rockefeller University, New York, NY) for the generous gift of anti-Ring2 antibody and anti-hBre1 serum. We thank Dr. Elena Cattaneo (University of Milan, Milan, Italy) and Dr. Marcy MacDonald for the generous gift of ST14a and STHdh cell lines, respectively.

Correspondence should be addressed to Dr. Jang-Ho J. Cha, MassGeneral Institute for Neurodegenerative Disease, Massachusetts General Hospital, 114 16th Street, Charlestown, MA 02129. E-mail: cha@helix.mgh.harvard.edu.

DOI:10.1523/JNEUROSCI.5667-07.2008

Copyright $\odot 2008$ Society for Neuroscience $\quad$ 0270-6474/08/283947-11\$15.00/0 ner, 1980). In higher eukaryotes, H2A is monoubiquitylated at lysine 119 (Nickel and Davie, 1989). It is linked to gene silencing such as repression of Ultrabithorax gene in Drosophila and $\mathrm{X}$-chromosome inactivation in female mammals (de Napoles et al., 2004; Wang et al., 2004). In contrast, H2B is monoubiquitylated at lysine 120 (Thorne et al., 1987). Several studies show that $\mathrm{H} 2 \mathrm{~B}$ monoubiquitylation is associated with actively transcribed chromatin (Nickel et al., 1989; $\mathrm{Ng}$ et al., 2003). However, the role for histone monoubiquitylation in the regulation of mammalian gene expression is primarily unknown.

Histone acetylation and methylation are involved in transcriptional dysregulation in HD (Steffan et al., 2001; Hockly et al., 2003; Ryu et al., 2006; Sadri-Vakili et al., 2007; Stack et al., 2007). However, histone acetylation is transient and does not adequately explain long-lasting transcriptional changes in HD. Interestingly, histone acetylation affects monoubiquityl histone $\mathrm{H} 2 \mathrm{~A}(\mathrm{uH} 2 \mathrm{~A})$ (Sadri-Vakili et al., 2007), a more durable modification, whereas $\mathrm{uH} 2 \mathrm{~B}$ controls histone methylation (Ng et al., 2002; Sun and Allis, 2002). Thus, histone monoubiquitylation is a potential bridge between histone acetylation and methylation, leading to changes in gene expression in HD. In addition, an increased recruitment of a transcriptional coactivator complex, STAGA/ TFTC, is involved in transcriptional dysregulation of spinocerebellar ataxia type 7 (SCA7), another polyglutamine disease (Helmlinger et al., 2004, 2006a,b). Because SAGA, the yeast homolog for mammalian STAGA, contains Ubp8, an enzyme for histone H2B deubiquitylation (Henry et al., 2003), H2B deubiquitylation by Ubp8 might induce transcriptional alterations in SCA7.

In this study, we have investigated whether histone monoubiquitylation plays a role in transcriptional dysregulation. We have identified molecular mechanisms by which mutant huntingtin alters histone monoubiquitylation and show that $\mathrm{uH} 2 \mathrm{~A}$ 
and $\mathrm{uH} 2 \mathrm{~B}$ have opposite effects on transcription in mouse and cell culture models of HD. This is the first report to show that histone monoubiquitylation regulates mammalian brain gene expression.

\section{Materials and Methods}

Transgenic R6/2 mice. Brains from R6/2 transgenic mice and wild-type littermate controls were used in experiments. R6/2 transgenic mice contain exon 1 of the $H D$ gene with an expanded CAG repeat (150-200) under control of the human HD promoter (Mangiarini et al., 1996). We purchased R6/2 transgenic mice from The Jackson Laboratory [code B6CBA-TgN (HDexon1); Bar Harbor, ME] and have maintained the colony by backcrossing R6/2 males to C57BL/6XCBA F1 females. Four-, eight-, and twelve-week-old R6/2 transgenic and wild-type littermate controls were killed, and brains were rapidly removed and frozen in liquid isopentane. Brains were stored at $-80^{\circ} \mathrm{C}$ until use. The guidelines for animal care and use were approved by the Massachusetts General Hospital Subcommittee on Research Animal Care.

Cell culture. Striatal cell lines were established from wild-type and STHdh (Q111) knock-in embryonic mice (Trettel et al., 2000). STHdh cell lines express full-length versions of either wild-type (containing 7 glutamines, STHdh $h^{7 / 7}$ ) or mutant (111 glutamines, STHdh ${ }^{111 / 111}$ ) huntingtin. Cells were kept in DMEM (Invitrogen, Gaithersburg, MD) plus $10 \%$ fetal bovine serum at $33^{\circ} \mathrm{C}$ for propagation and were placed at $39^{\circ} \mathrm{C}$ for $48 \mathrm{~h}$ to stop their division. ST14a cells, previously derived from rat embryonic striatum, were used to generate inducible cell lines expressing the N-terminal fragment of huntingtin (Sipione et al., 2002). ST14A cells and all subclones proliferate at $33^{\circ} \mathrm{C}$ but become postmitotic at $39^{\circ} \mathrm{C}$. Cells were grown in DMEM, supplemented as described previously (Cattaneo and Conti, 1998). Tet-free fetal calf serum (Clontech, Mountain View, CA) was used to supplement the medium for the inducible subclones (Tet-free medium).

Treatment of STHdh cells. STHdh ${ }^{7 / 7}$ cells kept at $39^{\circ} \mathrm{C}$ for $48 \mathrm{~h}$ were treated with 0.1-1 $\mu \mathrm{M}$ MG-132 (Calbiochem, La Jolla, CA) or 0.1-5 $\mu \mathrm{M}$ lactacystin (Calbiochem) for another $24 \mathrm{~h}$.

Western blotting. For Western blot analysis of uH2A, 10-40 $\mu \mathrm{g}$ of histone extracts, which were prepared as described by Ferrante and colleagues (Ferrante et al., 2004; Ryu and Ferrante, 2005) from wild-type and transgenic R6/2 mouse brains or STHdh cell lines, were resuspended in $2 \times$ tricine SDS sample buffer (Invitrogen, Carlsbad, CA). Samples were boiled at $100^{\circ} \mathrm{C}$ for $4 \mathrm{~min}$ and fractionated on a $10-20 \%$ tricine gel (Invitrogen) for $100 \mathrm{~min}$ at $120 \mathrm{~V}$. Proteins were transferred to polyvinylidene difluoride (PVDF) membranes in transfer buffer (3\% Tris base, $14.4 \%$ glycine, and $20 \%$ methanol) at $400 \mathrm{~mA}$ for $30 \mathrm{~min}$, and the PVDF was then blocked with $3 \%$ milk in distilled water for $1 \mathrm{~h}$ before immunodetection with anti-uH2A at lysine 119 antibody (Upstate Biotechnology, Lake Placid, NY) at a dilution of 1:500 overnight at $4^{\circ} \mathrm{C}$. Primary antibody incubation was followed by washes in distilled water before incubation with the secondary antibody (HRP-conjugated goat antirabbit IgG; Jackson ImmunoResearch, West Grove, PA) and visualization using the ECL detection system (NEN, Boston, MA). Protein membranes were stripped in stripping buffer (Pierce, Rockford, IL) for $30 \mathrm{~min}$ and reprobed with anti-H2A antibody (Upstate Biotechnology) at 1:1000 dilution overnight at $4^{\circ} \mathrm{C}$.

For uH2B Western blot analysis, $100 \mu \mathrm{g}$ of histone extracts from mouse brains or STHdh cell lines were immunoprecipitated with $2 \mu \mathrm{g}$ of anti-histone H2B antibody (Cell Signaling Technology, Danvers, MA) overnight at $4^{\circ} \mathrm{C}$ and protein A-agarose beads (Upstate Biotechnology) for $1 \mathrm{~h}$ at $4^{\circ} \mathrm{C}$. Immunoprecipitated complexes were then subjected to Western blot analysis with anti-ubiquitin antibody (Zymed, South San Francisco, CA) at 1:250 dilution overnight at $4^{\circ} \mathrm{C}$. For an internal control, anti-H2B antibody (Chemicon, Temecula, CA) was used at 1:1000 dilution overnight at $4^{\circ} \mathrm{C}$. Other antibodies used for Western blot analyses were as follows: Ring2 (provided by Dr. M. Vidal, Universidad Autonoma de Madrid, Madrid, Spain); Bmi-1 [mouse monoclonal antibody (Upstate Biotechnology) and rabbit polyclonal antibody (Proteintech Group, Chicago, IL)]; histone H1 (Upstate Biotechnology); glutathione S-transferase (GST; Chemicon); huntingtin (MAB 2166;
Chemicon); $\beta$-actin (Sigma, St. Louis, MO); hBre1 (provided by Dr. R. Roeder, Rockefeller University, New York, NY); and acetylated histone $\mathrm{H} 3$ at lysines 9 and 14, methylated histone $\mathrm{H} 3$ at lysine 4 or at lysine 9, heterochromatin protein $1 \alpha(\mathrm{HP} 1 \alpha)$, and $\mathrm{H} 3$ (all from Upstate Biotechnology). Optical density of individual protein bands was analyzed by using an image analysis program (Alpha Innotech, San Leandro, CA). Arbitrary units for optical density were displayed on the $y$-axis of each densitometry histogram. Statistical analysis on the optical density of the protein bands was performed on the mean \pm SEM, and levels of protein expression in these tissues were compared by $t$ test.

Immunofluorescence. Brain sections from wild-type and transgenic R6/2 were permeabilized with $0.5 \%$ Triton X-100 in $1 \times$ PBS for 20 min at room temperature (RT) and incubated with $50 \mu \mathrm{g} / \mathrm{ml}$ Affinipure Fab fragment goat anti-mouse IgM (for uH2A; Jackson ImmunoResearch) in $0.05 \%$ Tween 20 containing $1 \times$ PBS or $10 \%$ normal goat serum (NGS) in $1 \times$ PBS (for Ring2 and hBre1) for $1 \mathrm{~h}$ at RT. Then, sections were washed with $1 \times$ PBS and incubated in primary antibodies overnight at $4^{\circ} \mathrm{C}$ : anti-uH2A antibody (1:50 dilution with $0.05 \%$ Tween 20 containing PBS), anti-Ring2 antibody (1:500 dilution with $10 \%$ NGS in $1 \times$ PBS), and anti-hBrel serum (1:250 dilution with $10 \%$ NGS in $1 \times$ PBS). Sections were washed with $1 \times \mathrm{PBS}$ and incubated with secondary antibodies for $1 \mathrm{~h}$ at RT; for $\mathrm{uH} 2 \mathrm{~A}$, fluorescein (FITC) Affinipure Fab fragment goat anti-mouse IgM (Jackson ImmunoResearch) was used at 1:200 dilution in $0.05 \%$ Tween 20 containing PBS. For Ring2 and hBre1, Cy3 goat anti-rabbit IgG (Jackson ImmunoResearch) was used at 1:1500 or 1:750 dilution in $1 \times$ PBS, respectively. Sections were washed again with $1 \times$ PBS and mounted onto glass slides. Stained sections were examined under a confocal microscope.

GST pull-down assay. GST-Htt clones (HD20Q and HD53Q) were a generous gift from Dr. E. Wanker (Max-Planck Institute, Berlin, Germany). GST fusion proteins were prepared as described previously (Yohrling et al., 2003). Verification of protein synthesis was performed with SDS-PAGE and Coomassie Blue staining. One hundred micrograms of nuclear extracts from STHdh $h^{7 / 7}$ cells were incubated with $400 \mu \mathrm{g}$ of each GST-agarose, GST-exon $1 \mathrm{Htt}$ 20Q fusion protein-agarose, and GSTexon $1 \mathrm{Htt} 53 \mathrm{Q}$ fusion protein-agarose in buffer containing $10 \mathrm{~mm}$ Tris$\mathrm{HCl}, \mathrm{pH} 7.5,150 \mathrm{~mm} \mathrm{NaCl}, 0.1 \mathrm{~mm} \mathrm{Na}_{3} \mathrm{VO}_{4}, 30 \mathrm{~mm} \mathrm{Na}_{4} \mathrm{P}_{2} \mathrm{O}_{7}, 50 \mathrm{~mm}$ $\mathrm{NaF}, 1 \%$ Triton X-100, and protease inhibitor cocktail tablets (Roche Applied Science, Indianapolis, IN) at $4^{\circ} \mathrm{C}$ overnight. Agarose beads were washed four times with the buffer above, and proteins were extracted by heating at $100^{\circ} \mathrm{C}$ for $4 \mathrm{~min}$ in $30 \mu \mathrm{l}$ of $2 \times$ Tris-glycine sample buffer. The amount of Bmi-1 present in GST pull down was determined by Western blot analysis.

Coimmunoprecipitation. Two hundred micrograms of nuclear extracts from STHdh/7 cells were incubated with $1 \mu \mathrm{g}$ of anti-Htt (MAB2166; Chemicon) or anti-Bmi-1 (rabbit polyclonal antibody; Proteintech Group) antibody and $30 \mu \mathrm{l}$ of protein A-agarose beads (Upstate Biotechnology) at $4^{\circ} \mathrm{C}$ for $4-5 \mathrm{~h}$. The immune complexes were washed four times with the buffer used for GST pull-down assay and extracted by heating at $100^{\circ} \mathrm{C}$ for $4 \mathrm{~min}$ in $30 \mu \mathrm{l}$ of $2 \times$ Tris-glycine sample buffer. Then, the immune complexes were subjected to Western blot analysis for Bmi-1 or huntingtin protein.

Chromatin immunoprecipitation assay. We have adapted the chromatin immunoprecipitation (ChIP) technique to the analysis of brain tissue and have recently published a detailed methodology for performing ChIP experiments (Chen-Plotkin et al., 2006). Briefly, brain tissue or cells were subjected to cross-linking with formaldehyde. After crosslinking, the samples were homogenized and subjected to sonication, cleaving the chromatin into segments between 200 and 1000 bp in length. The cross-linked, sonicated samples were subjected to immunoprecipitation with anti-Bmi-1 antibody (Proteintech Group) or anti-uH2A antibody (Upstate Biotechnology). For uH2B ChIP, we immunoprecipitated ChIP homogenates with $1 \mu \mathrm{g}$ of anti-H2B antibody (Cell Signaling Technology, Beverly, MA). Then, the H2B-immunoprecipitated DNA samples were mixed in ChIP dilution buffer containing protease inhibitors (Chen-Plotkin et al., 2006) to give a $2 \mathrm{ml}$ volume, followed by a second immunoprecipitation with $20 \mu \mathrm{g}$ of anti-ubiquitin antibody (MAB1510; Chemicon). Specifically, antibody-histone-DNA complexes were pelleted with centrifugation and washed. Cross-links were 
A
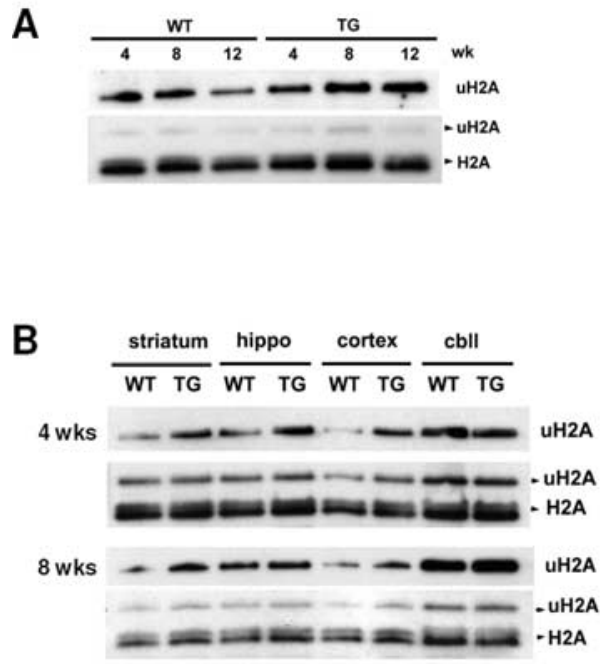

C

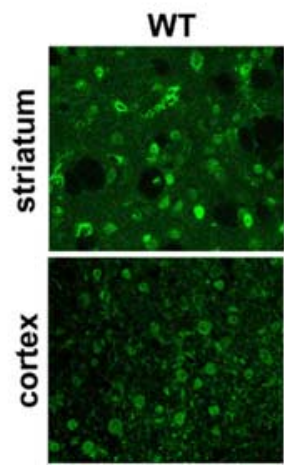

TG

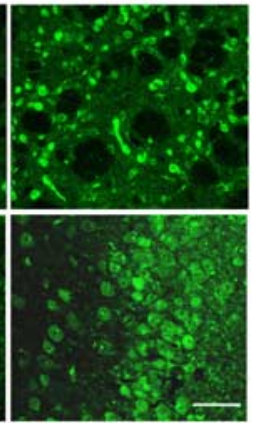

D

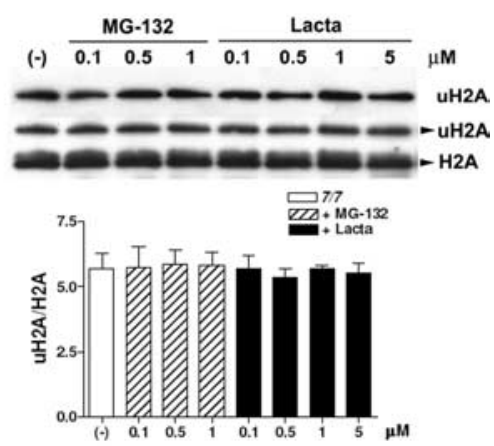

Figure 1. Increased $\mathrm{uH} 2 \mathrm{~A}$ in transgenic R6/2 brain. $\boldsymbol{A}$, Top, Western blot analyses probed with anti-uH2A antibody showing increased global uH2A levels in transgenic R6/2 whole brains at the age of 8 and 12 weeks compared with wild type. Bottom, This blot was stripped and reprobed with anti-H2A antibody, which recognizes both monoubiquitylated and unmodified $\mathrm{H} 2 \mathrm{~A}$, marked as $U \mathrm{H} 2 \mathrm{~A}$ and $\mathrm{H} 2 \mathrm{~A}$, respectively. To quantify uH2A levels, intensities of uH2A bands in the top panel were normalized to those of $\mathrm{H} 2 \mathrm{~A}$ bands in the bottom panel ( $\mathrm{uH} 2 \mathrm{~A} / \mathrm{H} 2 \mathrm{~A})$. Densitometry of $\mathrm{uH} 2 \mathrm{~A} / \mathrm{H} 2 \mathrm{~A}$ is shown on the right $\left(n=4\right.$ animals per group; ${ }^{*} p<$ 0.05). $\boldsymbol{B}$, Western blots showing increased global uH2A levels in 4 and 8 week transgenic R6/2 striatum, hippocampus, and cortex, but not cerebellum. Densitometry of $u H 2 A / H 2 A$ is shown on the right $\left(n=3\right.$ animals per group; $\left.{ }^{*} p<0.05\right)$. $C$, Confocal images of 12 week R6/2 brain sections stained with anti-uH2A antibody (scale bar, $50 \mu \mathrm{m}$ ). D, Western blots showing no change in uH2A in STHdh ${ }^{7 / 7}$ cells treated with MG-132 (0.1-1 $\mu \mathrm{m}$ ) or lactacystin (Lacta; $\left.0.1-5 \mu \mathrm{m}\right)$ for $24 \mathrm{~h}$. Densitometry of uH2A/H2A is shown below ( $n=4$ independent experiments). Error bars indicate SEM. TG, Transgenic; WT, wild type; wk(s), week(s); hippo, hippocampus; cbll, cerebellum.

reversed by a series of low- and high-salt washes. Proteins were degraded by the addition of proteinase K. DNA was extracted by phenol/chloroform and ethanol precipitation, followed by DNA quantitation. To verify the specificity of this $\mathrm{uH} 2 \mathrm{~B}$ ChIP technique, histone-DNA complexes after sequential ChIPs with anti-H2B and anti-ubiquitin antibodies were subjected to Western blot analyses for $\mathrm{uH} 2 \mathrm{~A}$ and $\mathrm{H} 2 \mathrm{~B}$.

DNA quantification. Immunoprecipitated DNA (from ChIP) was quantified using the DNA Quant System, which detects $10-500 \mathrm{pg} / \mu \mathrm{l}$ DNA (Promega, Madison, WI), according to the manufacturer's instructions. Briefly, a premix was made with a buffer solution containing sodium pyrophosphate, NDPK enzyme solution, and T4 DNA polymerase, aliquoted and mixed with either known DNA quantities (for a standard curve) or experimental unknown DNA quantities. The reaction was incubated for $10 \mathrm{~min}$ at $37^{\circ} \mathrm{C}$, chilled on ice for $30 \mathrm{~min}$ before mixing with ENLITEN luciferase reagent. The light output was immediately measured in a luminometer.

Real-time PCR. One microliter of ChIP-derived DNA was used as a

template in $20 \mu \mathrm{l}$ reactions containing $10 \mu \mathrm{l}$ of $2 \times$ SYBR Green Master Mix (Applied Biosystems, Foster City, CA) and $0.5 \mu \mathrm{M}$ of each primer. Real-time thermal cycling was performed using an iCycler thermal cycler (BioRad, Hercules, CA), with continuous SYBR Green monitoring according to the manufacturer's recommendations, using iCycler software. Cycling parameters for all amplifications were as follows: 60 cycles of $95^{\circ} \mathrm{C}$ for $30 \mathrm{~s}, 57^{\circ} \mathrm{C}$ for $30 \mathrm{~s}$, and $72^{\circ} \mathrm{C}$ for $45 \mathrm{~s}$, followed by meltcurve analysis $\left(55^{\circ} \mathrm{C}+\right.$ for $10 \mathrm{~s}$ for 80 cycles $)$. All PCRs were performed in triplicate and included negative controls (no DNA) as well as positive controls (serial dilutions of known amounts of genomic DNA). Primer sequences for real-time PCR are provided in supplemental Table 1 (available at www.jneurosci.org as supplemental material).

Real-time PCR data analysis. Target DNA sequence quantities were estimated from threshold amplification cycle numbers $\left(\mathrm{T}_{\mathrm{c}}\right)$ using $\mathrm{iCy}$ cler software. The $T_{c}$ value is determined as the cycle at which fluorescence (measured in relative fluorescence units) rises above a baseline threshold. Melt-curve analysis was also performed on all PCR products. Products were differentiated from primer-dimers based on melting temperatures, and PCR samples that had $<40 \%$ of the product melting at the appropriate temperature or product/primer-dimer ratios of $<2: 1$ were deemed to have insufficient DNA for analysis. For each gene sequence studied, a $\Delta \mathrm{T}_{\mathrm{c}}$ value was calculated for each sample by subtracting the value for the immunoprecipitated sample from the value for the corresponding input DNA to normalize for differences in ChIP sample aliquots before immunoprecipitation. DNA quantities were then expressed as percentages of corresponding input using the following equation: (antibody ChIP as a percentage of input $)=2^{(\Delta \mathrm{Tc})} \times 100$. DNA quantities (normalized to input) were compared for immunoprecipitated versus mock-immunoprecipitated samples. Data were analyzed with a one-way ANOVA, followed by Fisher's least significant difference method.

Small interfering RNA transfection. STHdh ${ }^{111 / 111}$ cells were transfected with small interfering RNA (siRNA) to mouse Ring2 (RNF2; Dharmacon, Lafayette, CO) or nontargeting control siRNA (Dharmacon) using Lipofectamine 2000 (Invitrogen) in OPTI-MEM I (Invitrogen) for 24-72 h. An siRNA to mouse hBrel (RNF20; Dharmacon) was transfected into STHdh/7 cells using Lipofectamine 2000 for 24-72 h. The final concentration of the siRNAs in cell culture medium was $100 \mathrm{~nm}$.

RNA extraction and reverse transcription. RNA was extracted from R6/2 dissected brain regions, STHdh cells, and ST14a cells using the RNeasy kit (Qiagen, Valencia, CA) according to the manufacturer's instructions. Reverse transcription reactions were performed using the Supescript First-Strand Synthesis System for reverse transcription-PCRs using specific primers to quantify the amount of gene expression.

\section{Results}

$\mathrm{uH} 2 \mathrm{~A}$ is increased in transgenic $\mathrm{R} 6 / 2$ mouse brain

The transgenic R6/2 mouse model of HD expresses exon 1 of the human HD gene containing $\sim 150$ CAG repeats (Mangiarini et al., 1996). We compared global levels of uH2A at lysine 119 
( $\mathrm{uH} 2 \mathrm{~A}$ ) in 4,8 , and 12 week transgenic R6/2 brains with those in wild-type brains by Western blot analyses of histone extracts with an antibody specific to $\mathrm{uH} 2 \mathrm{~A}$. Levels of $\mathrm{uH} 2 \mathrm{~A}$ were increased in transgenic whole brains at ages of 8 and 12 weeks (Fig. $1 A$ ). Furthermore, $\mathrm{uH} 2 \mathrm{~A}$ levels were increased in the transgenic striatum, hippocampus, and cortex at all ages tested: 4, 8, and 12 weeks (Fig. $1 B)$ (12 week data not shown). Brain sections of wild-type and transgenic mice $(4,8$, and 12 weeks) were stained with the anti-uH2A antibody, and striatum and cortex were examined with confocal microscopy. uH2A immunoreactivity localized in nuclei and was increased in transgenic striatum and cortex of all ages examined (Fig. 1C) (4 and 8 week data not shown).

\section{Proteasome inhibition does not affect $\mathrm{uH} 2 \mathrm{~A}$ levels}

To examine whether increased $\mathrm{uH} 2 \mathrm{~A}$ levels in transgenic R6/2 brains are the result of impairment of the ubiquitin proteasome machinery that has been observed in HD (Valera et al., 2005), we treated full-length wild-type Htt-knock-in STHdh${ }^{7 / 7}$ cells with proteasome inhibitors such as MG-132 (0.1-1 $\mu \mathrm{M})$ and lactacystin $(0.1-5 \mu \mathrm{M})$ for $24 \mathrm{~h}$. Levels of $\mathrm{uH} 2 \mathrm{~A}$ were not affected, indicating that increased $\mathrm{uH} 2 \mathrm{~A}$ levels are not attributable to proteasome inhibition (Fig. 1D).

\section{Bmi-1 binds to DNA more in the presence of mutant $\mathrm{Htt}$}

Recently, human Polycomb-repressive complex 1-like (hPRC1L; which is composed of several Polycomb group proteins including Ring1, Ring2, Bmi-1, and HPH2) was identified as an E3 ubiquitin ligase complex responsible for $\mathrm{H} 2 \mathrm{~A}$ monoubiquitylation (Wang et al., 2004). To examine whether a change in hPRC1L accounts for increased global levels of $\mathrm{uH} 2 \mathrm{~A}$, we first examined Ring2, the catalytic domain of hPRC1L, by immunofluorescence and Western blot. Ring2 immunofluorescence was observed in nuclei, but there was no difference in subcellular localization or immunopositivity of Ring2 between wild-type and transgenic R6/2 striatum and cortex at 4, 8, or 12 weeks of age (data not shown). We also confirmed that there was no difference in nuclear Ring 2 protein levels between 8 week wild-type and transgenic R6/2 by Western blot (Fig. 2A). Next, we looked at Bmi-1, the contribution of which to $\mathrm{H} 2 \mathrm{~A}$ monoubiquitylation is likely achieved through modulating the catalytic activity of Ring2 (Cao et al., 2005). Interestingly, we found that Bmi-1 was lower in nuclear extracts from 8 week transgenic striatum and cortex than those of wild type. But, it was detected more abundantly in histone extracts from 8 week transgenic striatum and cortex than those of wild type (Fig. 2A). Because histone extracts represent proteins present exclusively in nucleosomes such as histones, one possibility is that Bmi-1 protein binds more to nucleosomes in the presence of mutant Htt protein.

To address this possibility, we first examined whether there was an interaction between Htt and Bmi-1. In vitro GST pulldown assays using nuclear extracts from STHdh/7 cells showed that exon 1 wild-type Htt (20Q) fusion protein bounds to Bmi-1 more than exon 1 mutant $\mathrm{Htt}$ (53Q) fusion protein (Fig. 2 B). To see an endogenous interaction of Htt with Bmi-1, we immunoprecipitated nuclear extracts from wild-type Htt-expressing STHdh ${ }^{7 / 7}$ and mutant Htt-expressing (full-length mutant Httknock-in) STHdh ${ }^{111 / 111}$ cells with anti-Htt antibody and compared Bmi-1 in the immunoprecipitates by Western blot analyses. We found that wild-type Htt protein (from STHdh $h^{7 / 7}$ cells) bound to Bmi-1 more than mutant Htt (from STHdh ${ }^{111 / 111}$ cells) did. We also confirmed these Htt-Bmi-1 interactions by immunoprecipitating Bmi-1 and immunoblotting for $\mathrm{Htt}$, which
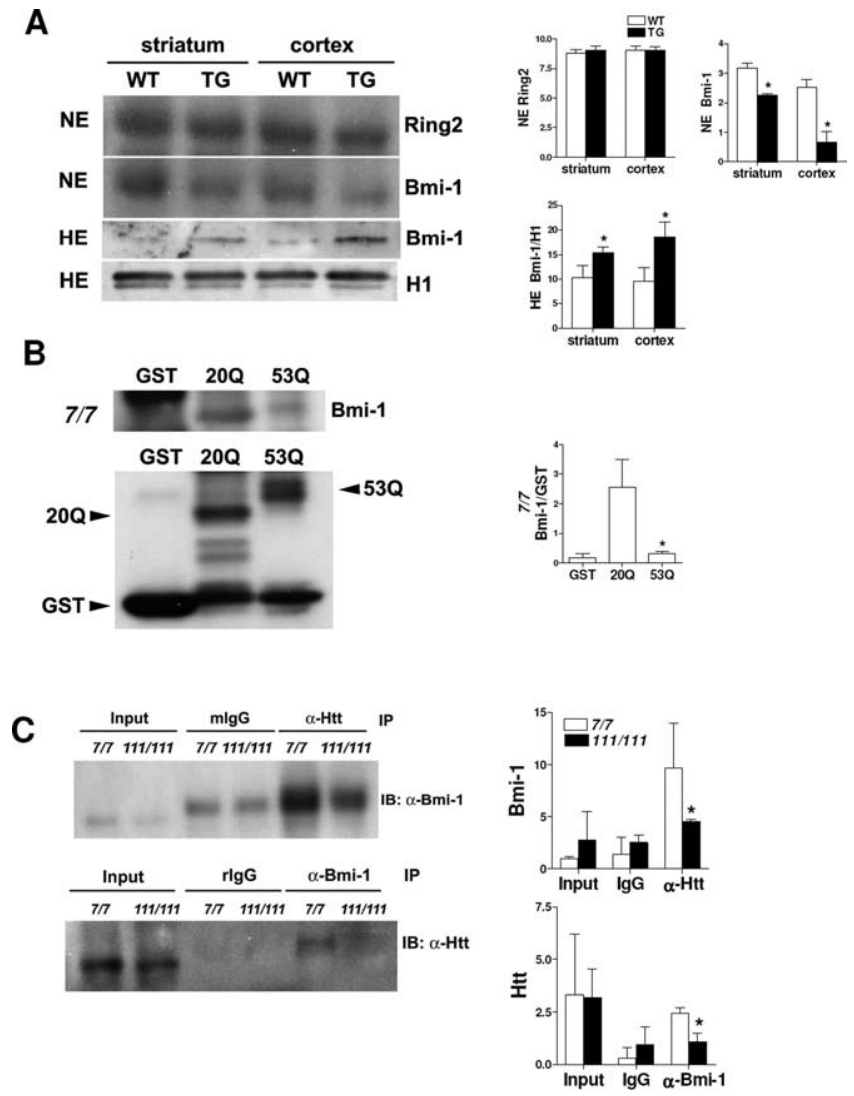

Figure 2. Increased Bmi-1 binding to DNA in the presence of mutant huntingtin $\boldsymbol{A}$, Top, Western blot showing no difference in the Ring 2 level in nuclear extracts (NE) between 8 week wild-type and transgenic R6/2 striatum and cortex. The blot was stripped and reprobed with anti-Bmi-1 antibody, which showed lower Bmi-1 in nuclear extracts from transgenic striatum and cortex. Densitometry of Ring 2 and Bmi- 1 is shown on the right ( $n=3$ animals per group; ${ }^{*} p<0.05$ ). Bottom, Western blot showing higher Bmi-1 levels in histone extracts (HE) from 8 week transgenic R6/2 striatum and cortex. The blot was stripped and reprobed with antihistone $\mathrm{H} 1$ antibody for an internal control. Bmi- 1 bands were normalized to $\mathrm{H} 1$ bands (Bmi-1/ $\mathrm{H} 1$ ), and densitometry of Bmi-1/H1 is shown on the right ( $n=3$ animals per group; ${ }^{*} p<0.05$ ). $\boldsymbol{B}$, GST pull-down assay showing Bmi- 1 in nuclear extracts from STHdh ${ }^{7 / 7}$ cells binds to GSTexon 1 wild-type Htt (200) but less binds to GST-exon 1 mutant Htt (530). One-tenth of nuclear extracts used for the pull-down assay were loaded as the input. Dark bands in the GST lane are nonspecific ones. Immunoblotting of GST alone, 20Q, and 530 proteins was performed with an anti-GST antibody. Then, Bmi-1 bands were normalized to GST bands (Bmi-1/GST.) Densitometry of Bmi-1/GST is shown on the right ( $n=3$ independent experiments; ${ }^{*} p<0.05,200$ vs 530). C, Coimmunoprecipitation (IP) with anti-Htt antibody showing wild-type $\mathrm{Htt}$ in STHdh ${ }^{7 / 7}$ cells binds to Bmi-1, but mutant Htt in STHdh ${ }^{111 / 111}$ does less. Another IP with anti-Bmi-1 antibody shows less Bmi-1 binding to mutant Htt than wild-type Htt. One-fifth of nuclear extracts used for the IPs were loaded as the input. Mouse (mlgG) and rabbit (rlgG) lgG are isotype-matched controls for the anti-Htt and anti-Bmi-1, respectively. Densitometry of Bmi-1 and $\mathrm{Htt}$ bands is shown below ( $n=3$ independent experiments; ${ }^{*} p<0.05$ ). IB, Immunoblot. Error bars indicate SEM.

showed Bmi-1 bound more to wild-type Htt than to mutant $\mathrm{Htt}$ (Fig. 2C). Together, these findings suggest that wild-type Htt binds to Bmi-1 more than mutant $\mathrm{Htt}$ and, in the presence of mutant Htt, free Bmi-1 might be more accessible to bind to DNA. To address this idea, we performed ChIP with an anti-Bmi-1 antibody on STHdh $h^{7 / 7}$ and STHdh $h^{111 / 111}$ cells and quantified DNA amounts by normalizing the amounts of DNA bound by Bmi-1 to those of input DNA. We found that Bmi-1 binds to DNA more in STHdh $h^{111 / 111}$ cells than in STHdh ${ }^{7 / 7}$ cells $(1.64 \pm$ $0.10 \%$ of input DNA was bound by Bmi-1 in STHdh ${ }^{111 / 111}$ cells, whereas $1.05 \pm 0.20 \%$ of input DNA was bound by Bmi-1 in $\mathrm{STH} d h^{7 / 7}$ cells). Thus, we suggest that Bmi-1 protein released 


\section{A 4 weeks}
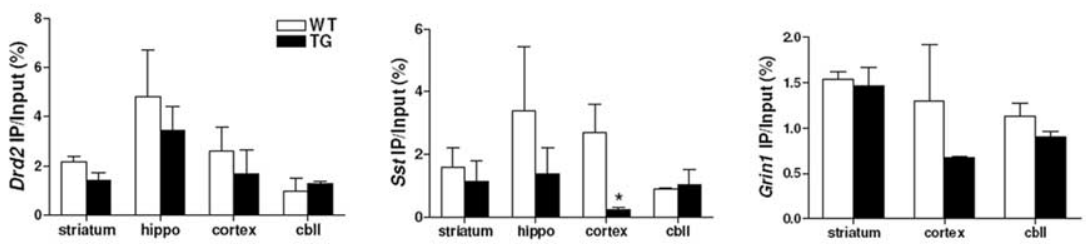

B
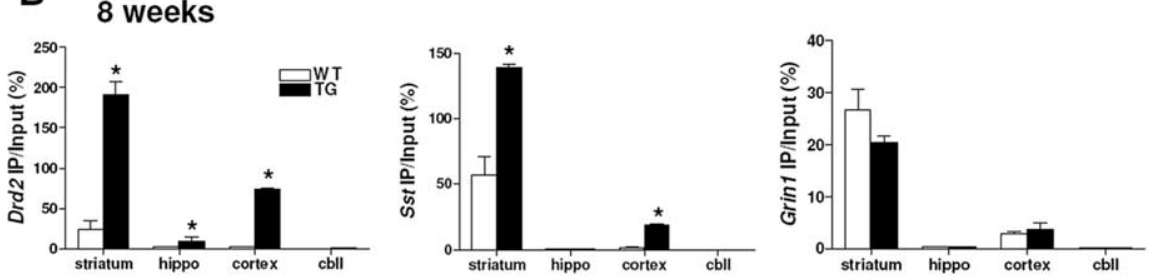

\section{12 weeks}
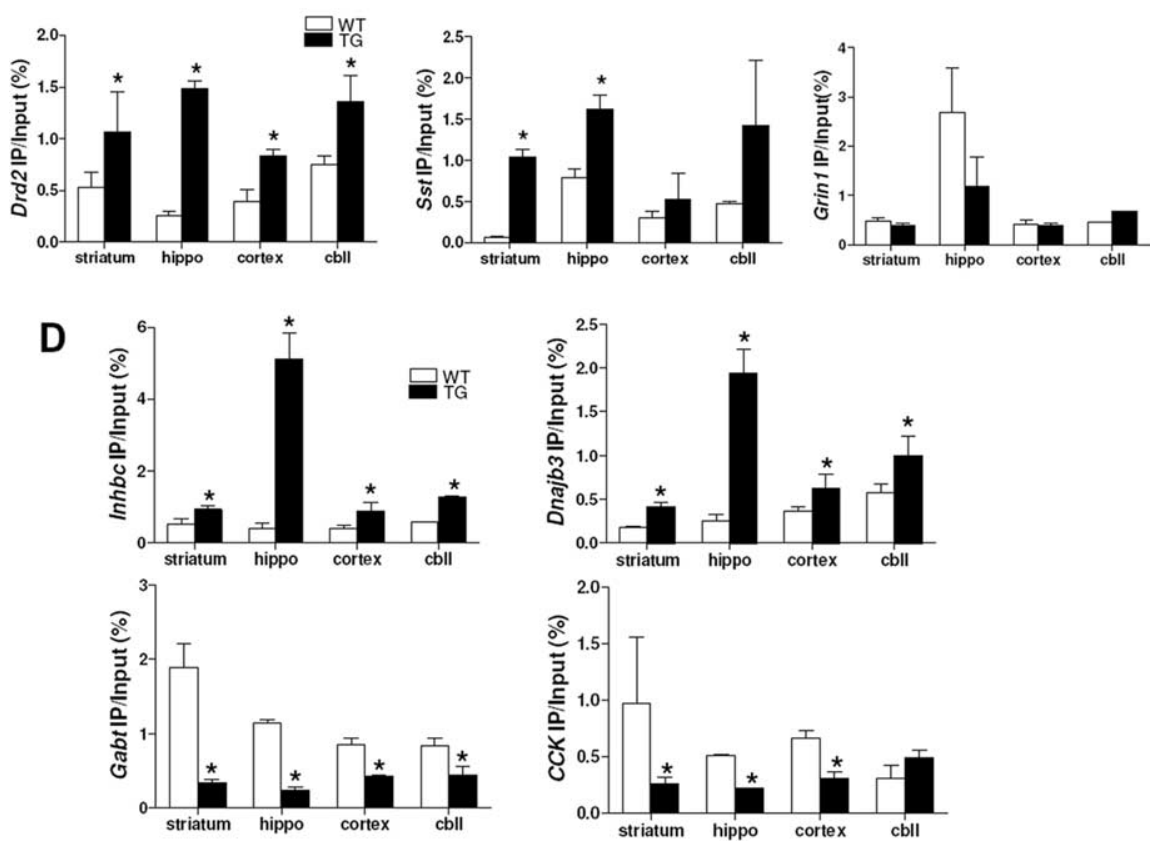

Figure 3. In vivo ChIP demonstrates that $\mathrm{uH} 2 \mathrm{~A}$ association with gene promoters inversely correlates with transcriptional activity in R6/2. A, No difference in uH2A association with Drd2, Sst, and Grin1 gene promoters between 4 week wild-type and transgenic R6/2 brain regions, except for decreased uH2A association with Sst gene promoter in transgenic cortex ( $n=3$ animals per group; ${ }^{*} p<0.05$ ). uH2A enrichment in Grin1 gene promoter in hippocampus (hippo) was below a detection limit in both wild-type and transgenic mice. $B$, Increased uH2A association with Drd2 gene promoter in 8 week transgenic striatum, hippocampus, and cortex but not cerebellum (cbll) compared with wild-type. Increased uH2A association with Sst gene promoter in 8 week transgenic striatum and cortex, but not in hippocampus or cerebellum ( $n=3$ animals per group; $\left.{ }^{*} p<0.05\right)$. C, Increased uH2A association with Drd 2 gene promoters in all brain regions of 12 week transgenic R6/2 compared with wild type but increased uH2A association with Sst gene promoter in 12 week R6/2 striatum and hippocampus ( $n=3$ animals per group; ${ }^{*} p<0.05$ ). D, Increased uH2A association with expressed-WT-only Inhbc and Dnaj3b gene promoters but decreased uH2A association with expressed-Tg-only Gabt and upregulated-Tg CCK gene promoters in all brain regions of 12 week transgenic mice, except for CCK in transgenic cerebellum, compared with wild type $\left(n=3\right.$ animals per group; $\left.{ }^{*} p<0.05\right)$. Error bars indicate SEM. TG, Transgenic; WT, wild type; hippo, hippocampus; cbll, cerebellum; IP, immunoprecipitation.

from mutant Htt binds to DNA, which might contribute to increased $\mathrm{uH} 2 \mathrm{~A}$ levels in transgenic R6/2 brains.

Association of $\mathrm{uH} 2 \mathrm{~A}$ with gene promoters inversely correlates with transcriptional activities of the genes in R6/2

To study whether $\mathrm{uH} 2 \mathrm{~A}$ is relevant to transcriptional dysregulation in $\mathrm{HD}$, we performed ChIP with an anti-uH2A antibody and quantitative real-time PCR with primers for the promoter regions of mouse $\mathrm{D}_{2}$ dopamine receptor ( $\mathrm{Drd} 2)$, preproenkephalin (Penk1), presomatostatin (Sst), the NR1 subunit of the NMDA receptor (Grin1), and $\beta$-actin (Actb) genes; expression of Drd2, Penk1, and Sst genes are known to be downregulated in HD, whereas Grin 1 and Actb expression are not changed (Luthi-Carter et al., 2000). Whole brains from 8 week transgenic R6/2 mice showed a significant increase in $\mathrm{uH} 2 \mathrm{~A}$ association with Drd2, Penk1, and Sst genes. However, there was no difference in $\mathrm{uH} 2 \mathrm{~A}$ association with Grin1 gene between wildtype and transgenic brains (supplemental Fig. S1 $A$, available at www.jneurosci.org as supplemental material). When we examined each brain region including striatum, hippocampus, cortex, and cerebellum, we found decreased $\mathrm{uH} 2 \mathrm{~A}$ association with Sst gene in 4 week transgenic cortex (Fig. $3 A$ ). Interestingly, in 8 and 12 week transgenic brain regions, we observed increased uH2A association with the Drd2, Penk1, and Sst gene promoters. In particular, striatum, which is the most affected area in $\mathrm{HD}$, consistently showed increased $\mathrm{uH} 2 \mathrm{~A}$ association with all downregulated genes tested. However, uH2A association with Grin1 and $A c t b$ gene promoters was not different between wild-type and transgenic brains (Fig. $3 B, C$ ) (Penk1 and Actb not shown). These findings suggest that increased $\mathrm{uH} 2 \mathrm{~A}$ binding to gene promoters is a marker for transcriptional repression, which becomes more prominent over the disease course. To investigate how $\mathrm{uH} 2 \mathrm{~A}$ is related to other gene changes, we analyzed $\mathrm{uH} 2 \mathrm{~A}$ enrichment at promoters of (1) genes that are expressed in wild-type brains but not transgenic brains (“expressed-WT-only") [inhibin $\beta$-C (In$h b c$ ) and DnaJ (Hsp40) homolog, subfamily B, member 3 (Dnajb3)], (2) genes that are expressed in transgenic brains but not wild-type brains ("expressed-Tg-only") $\left[\mathrm{GABA}_{\mathrm{A}}\right.$ subunit theta (Gabt) and DNA methyltransferase 1 associated protein 1 (Dmap1)], or (3) genes that are expressed more highly in transgenic brains ("upregulated-Tg") [cholecystokinin $(C C K)]$. Very interestingly, we observed increased $\mathrm{uH} 2 \mathrm{~A}$ association with $\operatorname{Inhbc}$ and Dnajb3 gene promoters but decreased $\mathrm{uH} 2 \mathrm{~A}$ association with Gabt, Dmap1, and CCK gene promoters in transgenic brain regions compared with wild type (Fig. 3D) (Dmap1 data not shown). Together, uH2A association with gene promoters appears to be specifically related to gene transcriptional activities (i.e., increased $\mathrm{uH} 2 \mathrm{~A}$ with "downregulated-Tg" and expressed-WT-only genes but decreased $\mathrm{uH} 2 \mathrm{~A}$ with upregulated-Tg and expressed-Tg-only genes in $\mathrm{R} 6 / 2$ brains). 
Association of $\mathrm{uH} 2 \mathrm{~A}$ with promoters of downregulated genes is increased in mutant Htt-inducible cells and full-length mutant Htt knock-in cells

To study whether increased $\mathrm{uH} 2 \mathrm{~A}$ association with downregulated genes is a universal phenomenon in $\mathrm{HD}$, we performed uH2A ChIP on parental ST14a (12.4), wild-type Htt-inducible (HD19), or mutant Htt-inducible (HD43) cells in the absence or presence of the inducer $(0.5 \mu \mathrm{g} / \mathrm{ml}$ doxycycline). HD 43 cells ( 105 glutamines) and HD19 cells (26 glutamines) overexpressed the N-terminal 548 amino acid fragment of mutant or wild-type $\mathrm{Htt}$, respectively (supplemental Fig. $\mathrm{S} 1 B$, available at www. jneurosci.org as supplemental material). ChIP and real-time PCR showed that there was increased $\mathrm{uH} 2 \mathrm{~A}$ association with $\mathrm{Drd} 2$ and Penk1 gene promoters in HD43 cells compared with that in 12.4 and HD19 cells when expression of Htt was induced by doxycycline. However, there was no difference in association of $\mathrm{uH} 2 \mathrm{~A}$ with Grin1 and Actb genes between doxycycline-added HD43 and HD19 cells (supplemental Fig. S1C, available at www.jneurosci.org as supplemental material).

We also analyzed $\mathrm{uH} 2 \mathrm{~A}$ association with gene promoters in another HD cell model, STHdh cells. Full-length mutant Httknock-in STHdh ${ }^{111 / 111}$ cells have different sets of downregulated genes from transgenic R6/2 brains, which include vitamin D receptor $(V d r)$, transcription factor 7 (Tcf7), inhibin $\beta$-b (Inhbb), and NADPH-dehydrogenase (Dhrs4) (Sadri-Vakili et al., 2007). We found increased $\mathrm{uH} 2 \mathrm{~A}$ association with those genes that are downregulated in STHdh ${ }^{111 / 111}$ cells. However, $\mathrm{uH} 2 \mathrm{~A}$ association with $A c t b$ (unchanged gene) promoter was equivalent in STHdh $h^{7 / 7}$ and STHdh ${ }^{111 / 111}$ cells (Fig. 4A).

\section{Ring2 knockdown rescues transcriptional repression in mutant Htt-knock-in cells}

To examine whether gene downregulation seen in HD can be corrected by reducing $\mathrm{uH} 2 \mathrm{~A}$ levels, we used an siRNA targeting Ring2 protein in STHdh ${ }^{111 / 111}$ cells. Ring2 siRNA knocked down Ring2 protein expression compared with mock and nontargeting control siRNA-transfected cells for all the time points examined (Fig. $4 B$ ). We confirmed that there was a dramatic decrease in $\mathrm{uH} 2 \mathrm{~A}$ levels in cells transfected with Ring2 siRNA for $24-48 \mathrm{~h}$ and that there was no change in total $\mathrm{H} 2 \mathrm{~A}$ levels in transfected cells (Fig. 4C). To examine mRNA levels in Ring2 siRNAtransfected cells, cDNAs from these cells were subjected to quantitative real-time PCR. Transcript levels were normalized to $\beta$-actin. Transcriptional repression of vitamin $\mathrm{D}$ receptor (VDR), transcription factor 7 (TCF7), and inhibin $\beta$-b (Inhibin b) was reversed in Ring2 siRNA-transfected cells (Fig. 4D). Together, these findings indicate that increased $\mathrm{uH} 2 \mathrm{~A}$ induces transcriptional repression and that $\mathrm{uH} 2 \mathrm{~A}$ is likely to play a causal role in transcriptional changes seen in HD.

\section{$\mathrm{uH} 2 \mathrm{~B}$ is decreased in transgenic $\mathrm{R} 6 / 2$ brain}

In contrast to $\mathrm{uH} 2 \mathrm{~A}$, histone $\mathrm{H} 2 \mathrm{~B}$ monoubiquitylated at lysine $120(\mathrm{uH} 2 \mathrm{~B})$ corresponds to actively transcribed chromatin (Nickel et al., 1989). We have analyzed global levels of uH2B by immunoprecipitating histone extracts from wild-type and transgenic R6/2 brains with an anti-H2B antibody and immunoblotting with an anti-ubiquitin (Ub) antibody. $\mathrm{uH} 2 \mathrm{~B}$ levels were very low, undetectable in 8 week transgenic whole brain (Fig. $5 A$ ). In 4 and 8 week transgenic mice, $\mathrm{uH} 2 \mathrm{~B}$ levels were undetectable in striatum and hippocampus but decreased in cerebellum compared with wild type (Fig. 5B) (8 week data not shown). To examine whether there is an alteration in hBre1, which is the E3 ubiquitin ligase specific to H2B (Kim et al., 2005; Zhu et al., 2005)
A

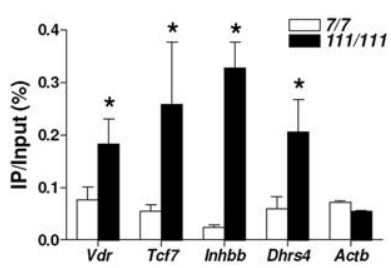

B

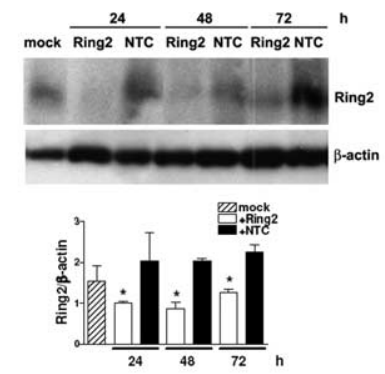

C

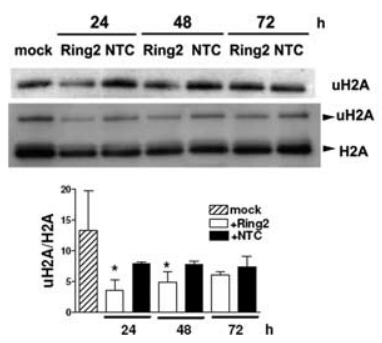

D
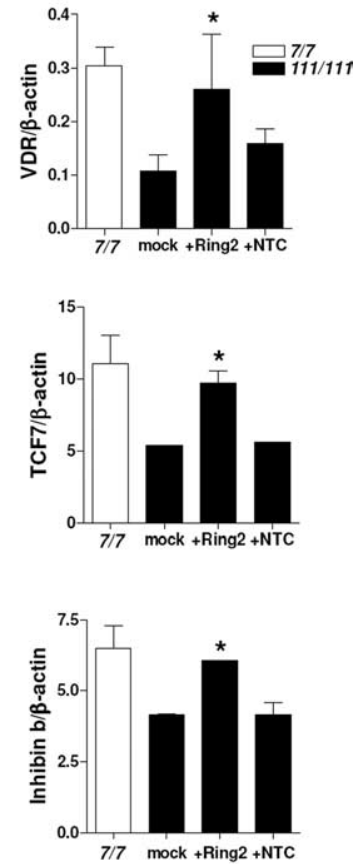

Figure 4. Increased $\mathrm{uH} 2 \mathrm{~A}$ association with genes downregulated in a cell culture model of $\mathrm{HD}$ and Ring2 knockdown-mediated reversal of transcriptional repression. $\boldsymbol{A}$, Increased $\mathrm{uH} 2 \mathrm{~A}$ association with $V d r, T c f 7$, Inhbb, and Dhrs 4 gene promoters in STHdh ${ }^{111 / 111}$ cells compared with STHd $h^{7 / 7}$ cells ( $n=3$ independent experiments; $\left.{ }^{*} p<0.05\right)$. B , Western blot showing a reduced Ring2 protein level in STHdh ${ }^{111 / 111}$ cells transfected with 100 nm Ring2 siRNA (Ring2) for 24-72 h. Mock or 100 nm nontargeting control siRNA (NTC)-transfected cells do not show a significant change in Ring2 protein level. For an internal control, the blot was stripped and reprobed for $\beta$-actin. Ring 2 bands were normalized to $\beta$-actin bands (Ring $2 / \beta$-actin), and densitometry of Ring $2 / \beta$-actin is shown below ( $n=3$ independent experiments; ${ }^{*} p<0.05$, Ring2 vs NTC). C, Western blot showing reduction in the uH2A level in STHdh ${ }^{111 / 111}$ cells transfected with 100 nm Ring 2 siRNA for $24-48$ h. Densitometry of uH2A/H2A is shown below ( $n=$ 4 independent experiments; ${ }^{*} p<0.05$, Ring 2 vs NTC). D, Quantitative real-time P(R showing increased mRNA levels of VDR, TCF7, and Inhibin b in STHdh ${ }^{111 / 111}$ cells transfected with $100 \mathrm{~nm}$ Ring 2 siRNA for $24 \mathrm{~h}$, which is equivalent to those in STHdh ${ }^{7 / 7}$ cells. mRNA levels of each gene normalized to that of $\beta$-actin gene are indicated as VDR/ $\beta$-actin, TCF7/ $\beta$-actin, and Inhibin b/ $\beta$-actin. Mock or NTC-transfected cells do not show any changes in mRNA levels of those genes ( $n=4$ independent experiments; ${ }^{*} p<0.05$, Ring 2 vs NTC). Error bars indicate SEM. IP, Immunoprecipitation.

to account for the decreased $\mathrm{uH} 2 \mathrm{~B}$ levels in transgenic mice, we stained brain sections from wild-type and transgenic mice at 4, 8, and 12 weeks of age with anti-hBrel serum. hBrel immunofluorescence was observed mainly in the peripheries of nuclei, but there was no difference in subcellular localization or protein level of hBre1, between wild-type and transgenic striatum and cortex areas of all the ages examined (Fig. 5C) (4 and 8 week data not shown).

\section{Association of $\mathrm{uH} 2 \mathrm{~B}$ with gene promoters positively} correlates with transcriptional activities of the genes in R6/2 To study whether the decreased global $\mathrm{uH} 2 \mathrm{~B}$ level is related to transcriptional dysregulation in $\mathrm{HD}$, we examined $\mathrm{uH} 2 \mathrm{~B}$ association with gene promoters by performing sequential ChIPs with anti-H2B and then anti-Ub antibodies. The specificity of this 
A
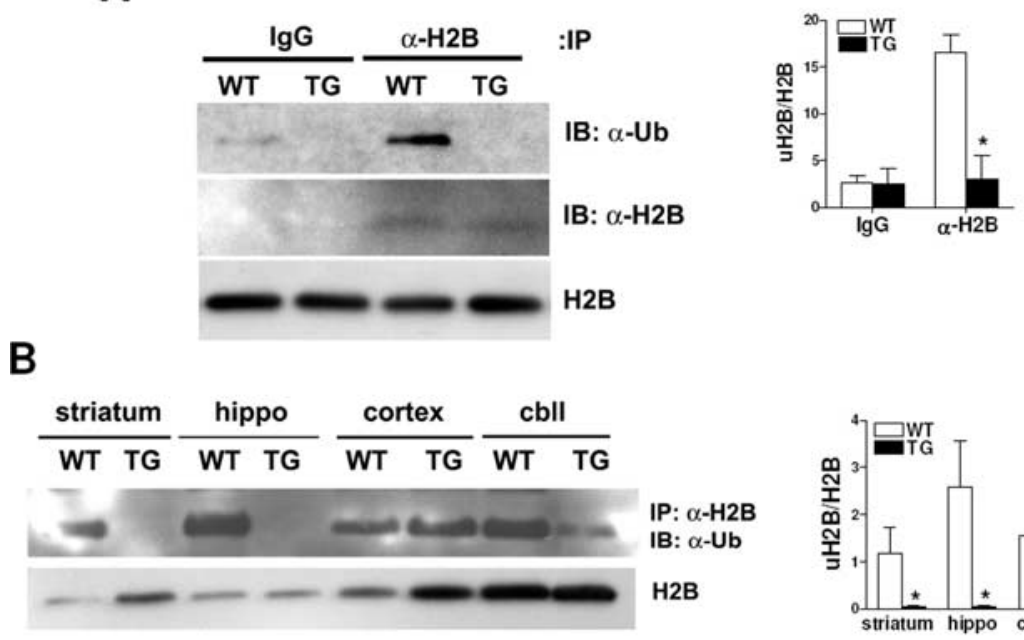

IP: $\alpha-\mathrm{H} 2 \mathrm{~B}$ IB: $\alpha-U b$ H2B

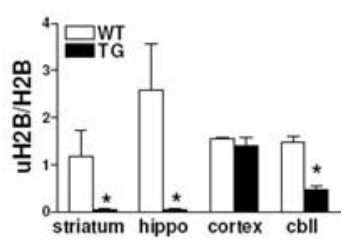

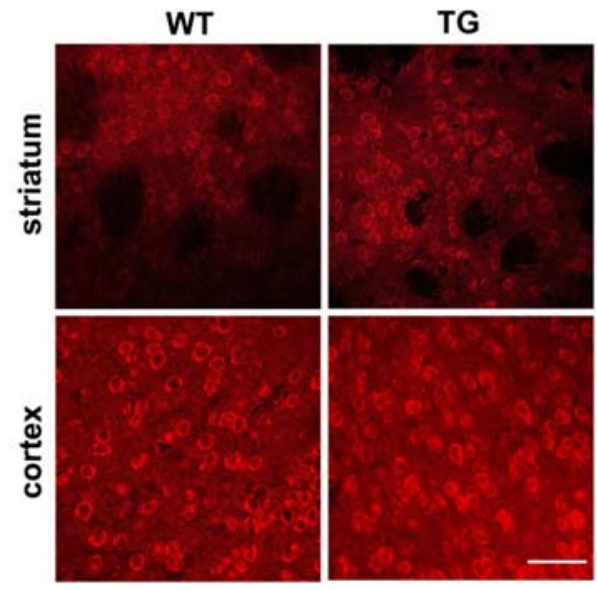

Figure 5. $u H 2 B$ is decreased in transgenic $\mathrm{R} 6 / 2$ brain. $A$, Western blot showing that the global uH2B level in 8 week transgenic $\mathrm{R} 6 / 2$ whole brains was below a detection limit of immunoprecipitation (IP) with $\lg \mathrm{G}$ or anti-H2B antibody followed by immunoblotting with anti-ubiquitin antibody (IB: $\alpha$-Ub). This blot was stripped and reprobed with anti-H2B antibody, which showed that the same amounts of $\mathrm{H} 2 \mathrm{~B}$ were pulled down from wild-type and transgenic mice (IB: $\alpha$-H2B). Western blot analysis of histone extracts also demonstrated $\mathrm{H} 2 \mathrm{~B}$ expression levels were equal in wild-type and transgenic mice (H2B). Densitometry of $\mathrm{UH} 2 \mathrm{~B} / \mathrm{H} 2 \mathrm{~B}$ is shown on the right $\left(n=4\right.$ animals per group; $\left.{ }^{*} p<0.05\right)$. B. Western blot showing global uH2B levels are undetectable in 4 week transgenic striatum and hippocampus and low in 4 week transgenic cerebellum. Western blot analysis of histone extracts from each brain region of 4 week mice demonstrated equal expression levels of $\mathrm{H} 2 \mathrm{~B}$ in wild-type and transgenic mice (H2B). Densitometry of uH2B/H2B is shown on the right ( $n=4$ animals per group; ${ }^{*} p<0.05$ ). $C$, Confocal images of 12 week wild-type and transgenic brains stained with anti-hBre1 serum (scale bar, $50 \mu \mathrm{m}$ ). Error bars indicate SEM. TG, Transgenic; WT, wild type; hippo, hippocampus; cbll, cerebellum.

uH2B ChIP technique was verified by subjecting the immunoprecipitated histone-DNA complexes to a Western analysis for $\mathrm{uH} 2 \mathrm{~A}$; no $\mathrm{uH} 2 \mathrm{~A}$ was detected in $\mathrm{uH} 2 \mathrm{~B}$ ChIP samples (supplemental Fig. S1 $D$, available at www.jneurosci.org as supplemental material). $\mathrm{uH} 2 \mathrm{~B}$ had decreased association with the $\mathrm{Drd} 2$ gene promoter in 8 week transgenic whole brain, but there was no difference in its association with the Grin 1 and $A c t b$ promoters between wild-type and transgenic brains (supplemental Fig. S1 E, available at www.jneurosci.org as supplemental material). Although decreased $\mathrm{uH} 2 \mathrm{~B}$ levels were detected as early as 4 weeks of age (Fig. $5 B$ ), uH2B association with the Drd2 and Sst gene promoters was increased in striatum but decreased in hippocampus of 4 week transgenic mice compared with wild type (Fig. 6A) (Sst data not shown). However, decreased $\mathrm{uH} 2 \mathrm{~B}$ association with $\operatorname{Drd2}$, Penk1, and Sst was observed in 8 and 12 week transgenic striatum, hippocampus, and cortex, but not cerebellum. There was no difference in $\mathrm{uH} 2 \mathrm{~B}$ association with Grin1 and $A c t b$ genes in each brain region between wild-type and transgenic mice (Fig. 6B,C) (8 week Sst and Grin1 and 12 week Penk1 and $A c t b$ data not shown). These results demonstrate that $\mathrm{uH} 2 \mathrm{~B}$ association with the downregulated genes decreases over the disease course. We also analyzed $\mathrm{uH} 2 \mathrm{~B}$ enrichment at promoters of expressed-WT-only (Inhbc and Dnajb3), expressed-Tg-only (Gabt and Dmap1), or upregulated-Tg (CCK) genes in 8 week R6/2 brains and found decreased $\mathrm{uH} 2 \mathrm{~B}$ association with $\mathrm{Inhbc}$ and Dnajb3 genes but increased association with Gabt, Dmap1, and CCK genes in 8 week transgenic brain regions (Fig. 6D) (Dmap1 data not shown). Together, uH2B association with gene promoters appears to positively correlate with transcriptional activities of the genes tested. These findings demonstrate that $\mathrm{H} 2 \mathrm{~B}$ monoubiquitylation is involved in transcriptional dysregulation in $\mathrm{HD}$ in the same way as $\mathrm{H} 2 \mathrm{~A}$ monoubiquitylation, which affects not only gene expression levels (upregulation or downregulation) but also genes being turned on and off (expressed-WT-only or expressed-Tg-only).

Association of $\mathrm{uH} 2 \mathrm{~B}$ with promoters of downregulated genes is decreased in mutant Htt-inducible cells and fulllength mutant Htt knock-in cells To study whether decreased $\mathrm{uH} 2 \mathrm{~B}$ association with downregulated genes is a universal phenomenon in $\mathrm{HD}$, we performed uH2B ChIP on parental ST14a (12.4), wild-type Htt-inducible (HD19), or mutant Htt-inducible (HD43) cells in the absence or presence of $0.5 \mu \mathrm{g} / \mathrm{ml}$ doxycycline. Immunoprecipitated DNAs were subjected to real-time PCR with primers for the promoter regions of rat $\operatorname{Drd} 2$, Penk1, Grin1, and Actb genes. In the presence of doxycycline, there was decreased $\mathrm{uH} 2 \mathrm{~B}$ association with Drd2 and Penk1 in HD43 cells compared with 12.4 and HD19 cells. However, there was no difference in association of $\mathrm{uH} 2 \mathrm{~B}$ with Grin1 and Actb genes between HD43 and HD19 cells (supplemental Fig. S1F, available at www.jneurosci.org as supplemental material). Association of $\mathrm{uH} 2 \mathrm{~B}$ with genes downregulated ( $V d r, T c f 7, \operatorname{Inh} b b$, and Dhrs4) in STHdh ${ }^{111 / 111}$ cells was also decreased, but uH2B association with $A c t b$ (unchanged gene) promoter was equivalent in STHdh $h^{7 / 7}$ and STHdh ${ }^{111 / 111}$ cells (Fig. 7A).

hBrel knockdown induces transcriptional repression in wildtype Htt knock-in cells

To determine whether $\mathrm{uH} 2 \mathrm{~B}$ alters gene expression, we manipulated $\mathrm{uH} 2 \mathrm{~B}$ levels by knocking down hBre1, the E3 ubiquitin ligase. The hBrel siRNA reduced hBrel and $\mathrm{uH} 2 \mathrm{~B}$ levels in STHdh $h^{7 / 7}$ cells, whereas mock and nontargeting control siRNA did not. There was no change in $\beta$-actin and $\mathrm{H} 2 \mathrm{~B}$ levels in hBre1 
siRNA-transfected cells (Fig. 7B). Levels of mRNA encoding VDR, TCF7, and Inhibin $b$ were decreased in hBrel siRNAtransfected cells. Mock and nontargeting control siRNA-transfected cells did not affect mRNA levels (Fig. 7C). These findings demonstrate that decreasing $\mathrm{uH} 2 \mathrm{~B}$ is sufficient to induce transcriptional repression and that $\mathrm{uH} 2 \mathrm{~B}$ is likely to play a causal role in transcriptional changes seen in HD.

$\mathrm{uH} 2 \mathrm{~A}$ affects methylation of histone $\mathrm{H} 3$ at lysine 9, whereas uH2B affects methylation of histone $\mathrm{H} 3$ at lysine 4 It would be important to understand how $\mathrm{uH} 2 \mathrm{~A}$ and $\mathrm{uH} 2 \mathrm{~B}$ are linked to each other and other histone modifications such as acetylation and methylation. Acetylation of histone $\mathrm{H} 3$ at lysines 9 and 14 (AcH3) and methylation of histone $\mathrm{H} 3$ at lysine 4 (methyl H3K4) are known to be involved in transcriptional activation (Roth et al., 2001; Santos-Rosa et al., 2002). Moreover, methyl H3K4 is known to be regulated by $\mathrm{uH} 2 \mathrm{~B}$ ( $\mathrm{Ng}$ et al., 2002; Sun and Allis, 2002). In contrast, methylation of histone $\mathrm{H} 3$ at lysine 9 (methyl H3K9) plays a role in transcriptional repression by recruiting heterochromatin protein 1 (HP1) (Bannister et al., 2001; Lachner et al., 2001).

We analyzed $\mathrm{uH} 2 \mathrm{~A}, \mathrm{uH} 2 \mathrm{~B}, \mathrm{AcH} 3$, methyl H3K4, methyl H3K9, and HP1 $\alpha$ levels in cells transfected with Ring 2 or hBrel siRNA by performing Western blot analyses. Reducing $\mathrm{uH} 2 \mathrm{~A}$ with Ring2 siRNA did not change $\mathrm{uH} 2 \mathrm{~B}, \mathrm{AcH} 3$, and methyl H3K4 levels (supplemental Fig. S2A, available at www.jneurosci.org as supplemental material). However, transfection with Ring2 siRNA significantly decreased di- and tri-methyl $\mathrm{H} 3 \mathrm{~K} 9$ and HP1 $\alpha$ (Fig. $8 A$ ). These results suggest that $\mathrm{uH} 2 \mathrm{~A}$ contributes to transcriptional repression by regulating proteins involved in heterochromatin formation such as methyl $\mathrm{H} 3 \mathrm{~K} 9$ and $\mathrm{HP} 1 \alpha$. However, reducing $\mathrm{uH} 2 \mathrm{~B}$ with hBrel siRNA did not affect $\mathrm{uH} 2 \mathrm{~A}, \mathrm{AcH} 3$, methyl H3K9, or HP1 $\alpha$ levels but decreased di- and tri-methyl H3K4 (Fig. $8 B$ and supplemental Fig. S2 B, available at www.jneurosci.org as supplemental material) (HP1 $\alpha$ not shown). Together, $\mathrm{uH} 2 \mathrm{~A}$ and $\mathrm{uH} 2 \mathrm{~B}$ are independent, and they do not affect acetylation of histone $\mathrm{H} 3$. However, histone monoubiquitylation regulates methylation of histone $\mathrm{H} 3$ at different lysine residues, which might play a role in determining transcriptional activities.

\section{Discussion}

Transcriptional changes in human HD and transgenic mouse models of HD suggest that mutant Htt exerts its toxic effects by disrupting gene expression important for neuronal survival and function. Although several pieces of evidence show that histone acetylation and methylation contribute to HD pathogenesis (Mc-

\section{A 4 weeks}

B 8 weeks

\section{12 weeks}
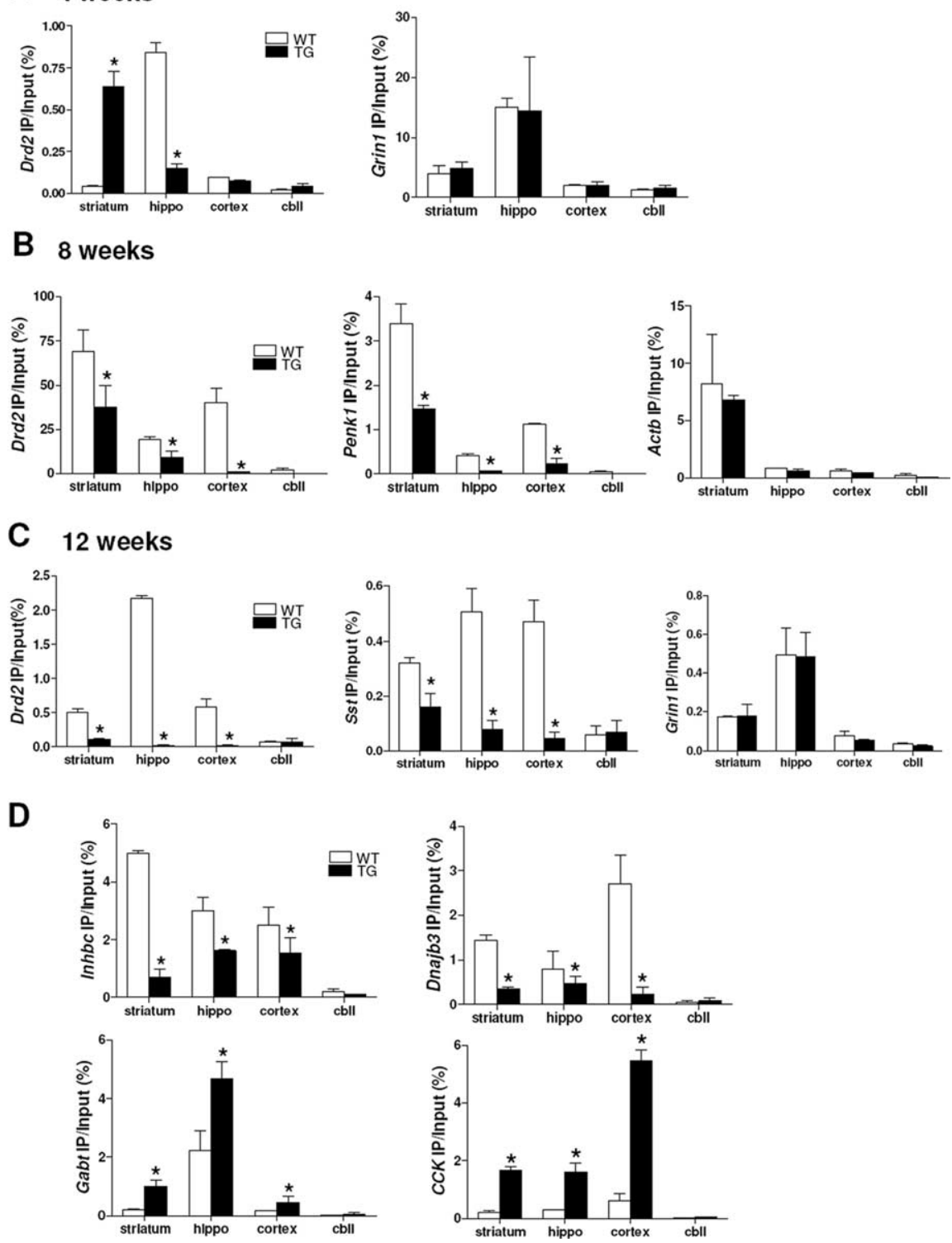

Figure 6. In vivo ChIP demonstrates that $\mathrm{UH} 2 \mathrm{~B}$ association with gene promoters positively correlates with transcriptional activity in R6/2.A, uH2B association with Drd2 gene promoter was increased in striatum but decreased in hippocampus of 4 week transgenic R6/2. No difference in $\mathrm{uH} 2 \mathrm{~B}$ association with $A c t b$ gene promoter between wild-type and transgenic mice $(n=3$ animals per group; ${ }^{*} p<0.05$ ). $\boldsymbol{B}$, Decreased $u$ H2B association with Drd2 and Penk1 gene promoters in 8 week transgenic striatum, hippocampus, and cortex, but not cerebellum, compared with wild type ( $n=3$ animals per group; ${ }^{*} p<0.05$ ). $\boldsymbol{C}$, Decreased uH2B association with Drd2 and Sst gene promoters in 12 week transgenic striatum, hippocampus, and cortex, but not cerebellum, compared with wild type ( $n=3$ animals per group; ${ }^{*} p<0.05$ ). D, Decreased uH2B association with expressed-WTonly Inhbc and Dnaj3b gene promoters but increased uH2B association with expressed-Tg-only Gabt and upregulated-Tg CCK gene promoters in 8 week transgenic striatum, hippocampus, and cortex, but not cerebellum, compared with wild type ( $n=4$ animals per group; $\left.{ }^{*} p<0.05\right)$. Error bars indicate SEM. TG, Transgenic; WT, wild type; hippo, hippocampus; cbll, cerebellum.

Campbell et al., 2001; Steffan et al., 2001; Hockly et al., 2003; Ryu et al., 2006; Sadri-Vakili et al., 2007; Stack et al., 2007), histone monoubiquitylation has not yet been studied. Given the known functions of uH2A (transcriptional repression) and H2B (transcriptional activation), we investigated whether histone monoubiquitylation plays a role in transcriptional dysregulation in HD. We addressed five major questions: (1) Do levels of $\mathrm{uH} 2 \mathrm{~A}$ and $\mathrm{H} 2 \mathrm{~B}$ differ between wild-type and transgenic R6/2 brains? (2) Does huntingtin affect monoubiquitylation of histone $\mathrm{H} 2 \mathrm{~A}$ and H2B? (3) Do levels of monoubiquityl histones at gene promoters correlate with transcriptional activity? (4) Does histone monou- 
A

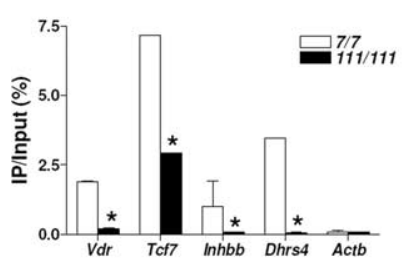

B

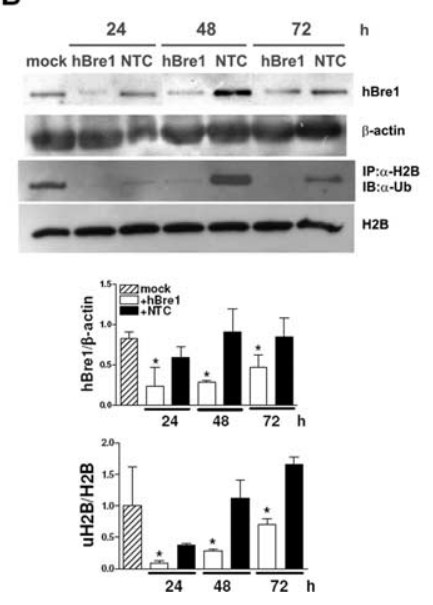

C
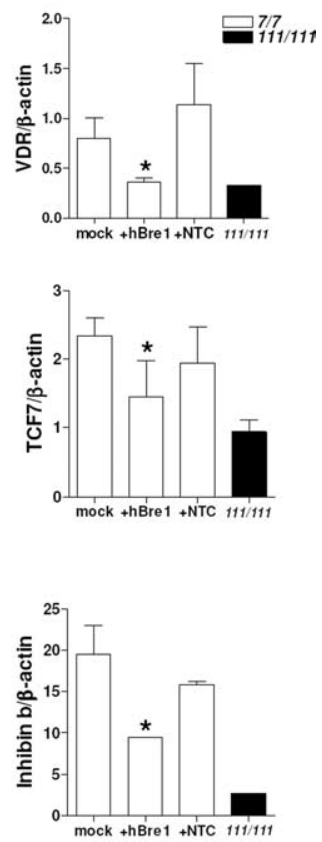

Figure 7. Decreased $\mathrm{uH} 2 \mathrm{~B}$ associations with genes downregulated in a cell culture model of $\mathrm{HD}$ and $\mathrm{hBre} 1$ knockdown-mediated transcriptional repression. $A$, Decreased uH2B association with Vdr, Tcf7, Inhbb, and Dhrs4 gene promoters in STHdh ${ }^{111 / 111}$ cells compared with that in STHdh ${ }^{7 / 7}$ cells ( $n=3$ independent experiments; ${ }^{*} p<0.05$ ). IP, Immunoprecipitation. $\boldsymbol{B}$, Western blot showing decreased levels of $\mathrm{hBre} 1$ and $\mathrm{UH} 2 \mathrm{~B}$ in $\mathrm{STHdh}{ }^{7 / 7}$ cells transfected with 100 nm hBre1siRNA (hBre1) for 24-72 h. Mock or nontargeting control siRNA (NTC)-transfected cells do not affect them. $\beta$-Actin and $\mathrm{H} 2 \mathrm{~B}$ were used as internal controls for hBre 1 and $\mathrm{uH} 2 \mathrm{~B}$, respectively. Densitometry of $\mathrm{hBre} 1 / \beta$-actin and $\mathrm{uH} 2 \mathrm{~B} / \mathrm{H} 2 \mathrm{~B}$ is shown below $(n=3$ independent experiments; ${ }^{*} p<0.05$, hBre1 vs NTC). C, Quantitative real-time PCR showing that decreased mRNA levels of VDR, TCF7, and Inhibin b in STHdh ${ }^{7 / 7}$ cells transfected with $100 \mathrm{~nm} \mathrm{hBre1}$ siRNA for $48 \mathrm{~h}$, which is equivalent to those in STHdh ${ }^{111 / 111}$ cells. mRNA levels of each gene normalized to that of $\beta$-actin gene are indicated as VDR/ $\beta$-actin, TCF7/ $\beta$-actin, and Inhibin $\mathrm{b} / \beta$-actin ( $n=4$ independent experiments; ${ }^{*} p<0.05$, hBre1 vs NTC). Error bars indicate SEM.

biquitylation induce transcriptional changes? (5) Does histone monoubiquitylation affect other histone modifications?

We found increased uH2A levels in transgenic R6/2 mouse striatum, hippocampus, and cortex at all the ages examined. Proteasome impairment does not appear to be involved in the regulation of the $\mathrm{uH} 2 \mathrm{~A}$ level (Fig. 1). To understand the molecular mechanisms underlying increased $\mathrm{uH} 2 \mathrm{~A}$ in the presence of $\mathrm{mu}-$ tant Htt protein, we examined Ring 2 and Bmi-1 of the mammalian Polycomb-repressive complex 1, termed hPRC1L, because it has an H2A-K119 ubiquitin E3 ligase activity. Ring2 is the catalytic subunit of hPRC1L, and Bmi-1 positively regulates $\mathrm{H} 2 \mathrm{~A}$ monoubiquitylation in a highly cooperative manner with Ring2 (Cao et al., 2005). Whereas there were no differences in subcellular localization, immunoreactivity, and nuclear protein levels of Ring2, there was a difference in Bmi-1 between wild-type and transgenic R6/2 (Fig. 2). On the basis of in vitro binding experiments with recombinant GST proteins and in vivo coimmunoprecipitation, wild-type $\mathrm{Htt}$ was found to bind to Bmi-1, whereas mutant Htt bound less, which might result in more Bmi-1 binding to DNA (Fig. 2). We thus identify hPRC1L as a histone modifying complex that interacts with huntingtin. Additionally, our study provides a clue to understanding normal physiological

functions of wild-type Htt, which is that wild-type Htt might regulate transcriptional activity by limiting the availability of Bmi-1 binding to gene promoters.

We also found decreased $\mathrm{uH} 2 \mathrm{~B}$ levels in transgenic R6/2 brains (Fig. 5). As is the case with Ring2 for $\mathrm{uH} 2 \mathrm{~A}$, subcellular localization or immunoreactivity of the E3 ubiquitin ligase for $\mathrm{H} 2 \mathrm{~B}$, termed hBre1, was not different between wild-type and transgenic R6/2 brains. We did not observe an interaction between Htt and hBrel with GST pull-down assays using the recombinant GST-Htt proteins and nuclear extracts from $\mathrm{STH} \mathrm{h}^{7 / 7}$ cells (data not shown). The ubiquitin protease Ubp8 mediates deubiquitylation of histone H2B in Saccharomyces cerevisiae (Henry et al., 2003). In Drosophila, the ubiquitin-specific protease 7-guanosine 5'-monophosphate synthetase complex catalyzes the selective deubiquitylation of histone H2B but not H2A (van der Knaap et al., 2005). However, the mammalian ubiquitinase specific to $\mathrm{uH} 2 \mathrm{~B}$ has not yet been identified. Thus, activity of hBrel or changes in yet-unidentified $\mathrm{uH} 2 \mathrm{~B}$ ubiquitinase would be interesting venues to investigate in HD.

Although global levels of $\mathrm{uH} 2 \mathrm{~A}$ were increased and global levels of $\mathrm{uH} 2 \mathrm{~B}$ were decreased in transgenic mouse brain, their levels in the promoters of specific single genes varied depending on transcriptional activities of genes. The promoters of the downregulated-Tg and expressed-WT-only genes in R6/2 mice have increased $\mathrm{uH} 2 \mathrm{~A}$ association and decreased $\mathrm{uH} 2 \mathrm{~B}$ association, which was observed mostly after 4 weeks of age (Figs. 3, 6). However, association of $\mathrm{uH} 2 \mathrm{~A}$ or $\mathrm{uH} 2 \mathrm{~B}$ with the unchanged genes in R6/2 was compatible between wild-type and transgenic $\mathrm{R} 6 / 2$. This relationship of monoubiquityl histones with the downregulated genes was recapitulated in cell culture models of $\mathrm{HD}$, in both Htt-inducible cell lines (ST14a) and full-length Htt knock-in cells (STHdh) (Figs. 4, 7, and supplemental Fig. S1, available at www.jneurosci.org as supplemental material). Furthermore, we found that the promoters of the upregulated-Tg and expressed-Tg-only genes in R6/2 have decreased $\mathrm{uH} 2 \mathrm{~A}$ and increased $\mathrm{uH} 2 \mathrm{~B}$ association. Therefore, our results provide strong evidence that $\mathrm{uH} 2 \mathrm{~A}$ and $\mathrm{uH} 2 \mathrm{~B}$ levels at promoters could be used as a marker for transcriptional activity of genes; transcriptionally inactive genes have high $\mathrm{uH} 2 \mathrm{~A}$ and low $\mathrm{uH} 2 \mathrm{~B}$ levels at their promoters, whereas transcriptionally active gene promoters have low $\mathrm{uH} 2 \mathrm{~A}$ and high $\mathrm{uH} 2 \mathrm{~B}$ levels.

Reduction in $\mathrm{uH} 2 \mathrm{~A}$ by siRNA-mediated knockdown of Ring2 corrected mRNA levels of certain genes known to be downregulated in STHdh ${ }^{111 / 111}$ cells (Fig. 4). In contrast, reduction in $\mathrm{uH} 2 \mathrm{~B}$ by hBrel siRNA induced transcriptional repression of those genes in STHdh $h^{7 / 7}$ cells (Fig. 7). Therefore, we successfully demonstrated that increased $\mathrm{uH} 2 \mathrm{~A}$ and decreased $\mathrm{uH} 2 \mathrm{~B}$ indeed induce transcriptional changes in our cell culture model of HD. These findings strongly suggest that $\mathrm{uH} 2 \mathrm{~A}$ and $\mathrm{uH} 2 \mathrm{~B}$ play a causal role in transcriptional dysregulation in human HD as well as R6/2 transgenic mice. In addition, the histone monoubiquitylation pathway could be a potential therapeutic target for HD. For instance, correcting $\mathrm{uH} 2 \mathrm{~A}$ level by targeting Ring2 protein might rescue transcriptional abnormalities and thereby the phenotype of HD.

The molecular mechanisms underlying uH2A-mediatedtranscriptional repression, particularly in mammalian systems remain primarily unknown. Recently, Cul4 (E3 ubiquitin ligase) was shown to play a role in the assembly of closed heterochromatin by recruiting Clr4 (histone $\mathrm{H} 3$ methyltransferase) and HP1 into nucleosomes in yeast (Jia et al., 2005). It was also demonstrated that $\mathrm{H} 2 \mathrm{~A}$ is a substrate for Cul4 in the context of DNA damage repair (Kapetanaki et al., 2006). Interestingly, we found 
that $\mathrm{uH} 2 \mathrm{~A}$ functions upstream of di- and tri-methyl histone $\mathrm{H} 3$ at lysine 9 (H3K9) and HPl $\alpha$ (Fig. 8). Both di- and trimethylation of $\mathrm{H} 3 \mathrm{~K} 9$ are predominant marks of heterochromatin, and $\mathrm{HP} 1 \alpha$ is associated mainly with centromeric heterochromatin in mammalian cells (Schotta et al., 2002; Peters et al., 2003). Because heterochromatin is linked to transcriptional repression, we hypothesize that increased $\mathrm{uH} 2 \mathrm{~A}$ in certain DNA regions favors heterochromatin and results in transcriptional repression.

In contrast, the molecular mechanisms by which $\mathrm{uH} 2 \mathrm{~B}$ regulates transcriptional activation are relatively well known. $\mathrm{uH} 2 \mathrm{~B}$ functions upstream of methylation of histone $\mathrm{H} 3$ at lysine $4(\mathrm{H} 3 \mathrm{~K} 4)$ and then at lysine 79 (H3K79); specifically, it is required for the transition from monomethylation to subsequent methylation of H3K4 (Shahbazian et al., 2005). In concordance, our results showed that hBrelmediated $\mathrm{uH} 2 \mathrm{~B}$ affects di- and trimethylation of H3K4 (Fig. 8). But uH2A and $\mathrm{uH} 2 \mathrm{~B}$ do not affect each other or acetylation of histone $\mathrm{H} 3$ at lysines 9 and 14 (supplemental Fig. S2, available at www. jneurosci.org as supplemental material). Together, we identified the new relationships between histone modifications; monoubiquityl $\mathrm{H} 2 \mathrm{~A}$ and $\mathrm{H} 2 \mathrm{~B}$ are independent from each other but function upstream of histone $\mathrm{H} 3$ methylation, albeit at different lysine residues.

We provide a comprehensive evaluation of the possibility that histone monoubiquitylation plays a crucial role in mutant Htt-mediated transcriptional dysregulation. Our data indicate that monoubiquitylation of histone $\mathrm{H} 2 \mathrm{~A}$ and deubiquitylation of $\mathrm{H} 2 \mathrm{~B}$ are two key alterations responsible for transcriptional changes in HD. This mechanism appears to be achieved through a huntingtin-interacting histone modifying complex, hPRC1L, and methylation of histone H3, which broadens our understanding of the histone code. This is the first report to demonstrate involvement of $\mathrm{uH} 2 \mathrm{~A}$ and $\mathrm{uH} 2 \mathrm{~B}$ in mammalian brain gene expression. Our findings also imply that histone monoubiquitylation is a potential target for HD therapy.

\section{References}

Augood SJ, Faull RL, Emson PC (1997) Dopamine D1 and D2 receptor gene expression in the striatum in Huntington's disease. Ann Neurol 42:215-221.

Bannister AJ, Zegerman P, Partridge JF, Miska EA, Thomas JO, Allshire RC, Kouzarides T (2001) Selective recognition of methylated lysine 9 on histone H3 by the HP1 chromo domain. Nature 410:120-124.

Cao R, Tsukada Y, Zhang Y (2005) Role of Bmi-1 and Ring1 A in H2A ubiquitylation and Hox gene silencing. Mol Cell 20:845-854.

Cattaneo E, Conti L (1998) Generation and characterization of embryonic striatal conditionally immortalized ST14A cells. J Neurosci Res 53:223-234.

Cha JH, Kosinski CM, Kerner JA, Alsdorf SA, Mangiarini L, Davies SW, Penney JB, Bates GP, Young AB (1998) Altered brain neurotransmitter receptors in transgenic mice expressing a portion of an abnormal human Huntington disease gene. Proc Natl Acad Sci USA 95:6480-6485.
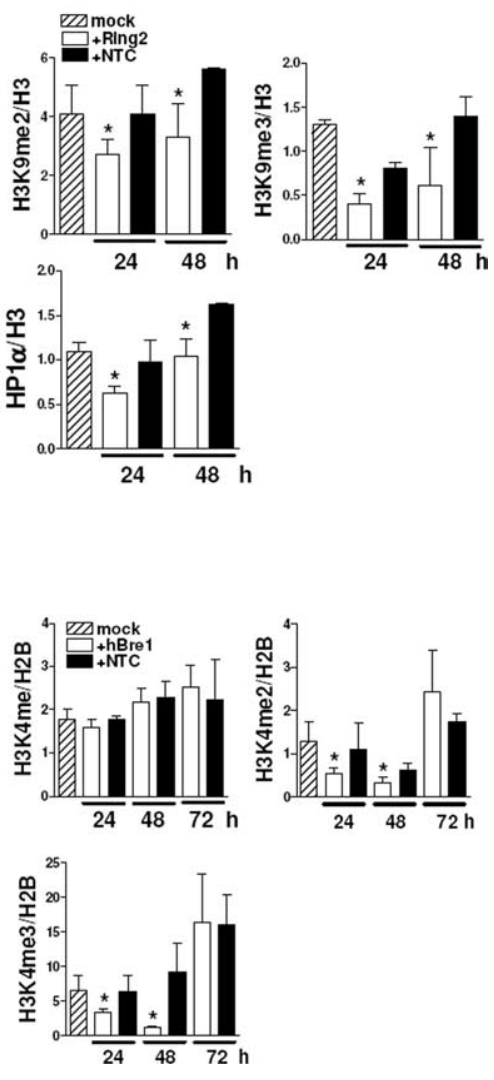

H3K4me3

H2B

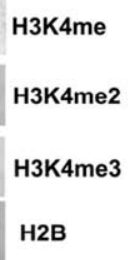

$\overline{24} \frac{}{48} \frac{}{72} \mathrm{~h}$

Figure 8. $\mathrm{uH} 2 \mathrm{~A}$ regulates methylation of histone $\mathrm{H} 3$ at lysine 9 and recruitment of $\mathrm{HP} 1 \alpha$, whereas $\mathrm{UH} 2 \mathrm{~B}$ regulates methylation ne $\mathrm{H3}$ at lysine 4. $\boldsymbol{A}$, Western blots showing decreased histone $\mathrm{H3}$ di- and tri-methylation at lysine 9 (H3K9me2 and change in monomethyl histone $\mathrm{H} 3$ at lysine 4 (H3K4me) in $\mathrm{STHdh}^{7 / 7}$ cells transfected with hBre1 siRNA for $24-72 \mathrm{~h}$. H2B was used as an internal control. Densitometry of $\mathrm{H} 3 \mathrm{~K} 4 \mathrm{me} / \mathrm{H} 2 \mathrm{~B}, \mathrm{H} 3 \mathrm{~K} 4 \mathrm{me} 2 / \mathrm{H} 2 \mathrm{~B}$, and $\mathrm{H} 3 \mathrm{~K} 4 \mathrm{me} 3 / \mathrm{H} 2 \mathrm{~B}$ is shown on the right $(n=3$ independent experiments; ${ }^{*} p<0.05$, hBre1 vs NTC). Error bars indicate SEM.

Chen-Plotkin AS, Sadri-Vakili G, Yohrling GJ, Braveman MW, Benn CL, Glajch KE, Dirocco DP, Farrell LA, Krainc D, Gines S, Macdonald ME, Cha JH (2006) Decreased association of the transcription factor Sp1 with genes downregulated in Huntington's disease. Neurobiol Dis 22:233-241.

de Napoles M, Mermoud JE, Wakao R, Tang YA, Endoh M, Appanah R, Nesterova TB, Silva J, Otte AP, Vidal M, Koseki H, Brockdorff N (2004) Polycomb group proteins Ring1A/B link ubiquitylation of histone H2A to heritable gene silencing and X inactivation. Dev Cell 7:663-676.

Ferrante RJ, Ryu H, Kubilus JK, D’Mello S, Sugars KL, Lee J, Lu P, Smith K, Browne S, Beal MF, Kristal BS, Stavrovskaya IG, Hewett S, Rubinsztein DC, Langley B, Ratan RR (2004) Chemotherapy for the brain: the antitumor antibiotic mithramycin prolongs survival in a mouse model of Huntington's disease. J Neurosci 24:10335-10342.

Goldknopf IL, Taylor CW, Baum RM, Yeoman LC, Olson MO, Prestayko AW, Busch H (1975) Isolation and characterization of protein A24, a "histone-like" non-histone chromosomal protein. J Biol Chem 250:7182-7187.

Helmlinger D, Hardy S, Sasorith S, Klein F, Robert F, Weber C, Miguet L, Potier N, Van-Dorsselaer A, Wurtz JM, Mandel JL, Tora L, Devys D (2004) Ataxin-7 is a subunit of GCN5 histone acetyltransferasecontaining complexes. Hum Mol Genet 13:1257-1265.

Helmlinger D, Hardy S, Eberlin A, Devys D, Tora L (2006a) Both normal and polyglutamine-expanded ataxin-7 are components of TFTC-type GCN5 histone acetyltransferase-containing complexes. Biochem Soc Symp 155-163.

Helmlinger D, Hardy S, Abou-Sleymane G, Eberlin A, Bowman AB, Gansmuller A, Picaud S, Zoghbi HY, Trottier Y, Tora L, Devys D (2006b) 
Glutamine-expanded ataxin-7 alters TFTC/STAGA recruitment and chromatin structure leading to photoreceptor dysfunction. PLoS Biol 4:e67.

Henry KW, Wyce A, Lo WS, Duggan LJ, Emre NC, Kao CF, Pillus L, Shilatifard A, Osley MA, Berger SL (2003) Transcriptional activation via sequential histone $\mathrm{H} 2 \mathrm{~B}$ ubiquitylation and deubiquitylation, mediated by SAGA-associated Ubp8. Genes Dev 17:2648-2663.

Hockly E, Richon VM, Woodman B, Smith DL, Zhou X, Rosa E, Sathasivam K, Ghazi-Noori S, Mahal A, Lowden PA, Steffan JS, Marsh JL, Thompson LM, Lewis CM, Marks PA, Bates GP (2003) Suberoylanilide hydroxamic acid, a histone deacetylase inhibitor, ameliorates motor deficits in a mouse model of Huntington's disease. Proc Natl Acad Sci USA 100:2041-2046.

Hodges A, Strand AD, Aragaki AK, Kuhn A, Sengstag T, Hughes G, Elliston LA, Hartog C, Goldstein DR, Thu D, Hollingsworth ZR, Collin F, Synek B, Holmans PA, Young AB, Wexler NS, Delorenzi M, Kooperberg C, Augood SJ, Faull RL, et al. (2006) Regional and cellular gene expression changes in human Huntington's disease brain. Hum Mol Genet 15:965-977.

Jason LJ, Moore SC, Lewis JD, Lindsey G, Ausio J (2002) Histone ubiquitination: a tagging tail unfolds? BioEssays 24:166-174.

Jia S, Kobayashi R, Grewal SI (2005) Ubiquitin ligase component Cul4 associates with $\mathrm{Clr} 4$ histone methyltransferase to assemble heterochromatin. Nat Cell Biol 7:1007-1013.

Kapetanaki MG, Guerrero-Santoro J, Bisi DC, Hsieh CL, Rapic-Otrin V, Levine AS (2006) The DDB1-CUL4ADDB2 ubiquitin ligase is deficient in xeroderma pigmentosum group $\mathrm{E}$ and targets histone $\mathrm{H} 2 \mathrm{~A}$ at $\mathrm{UV}$ damaged DNA sites. Proc Natl Acad Sci USA 103:2588-2593.

Kim J, Hake SB, Roeder RG (2005) The human homolog of yeast BRE1 functions as a transcriptional coactivator through direct activator interactions. Mol Cell 20:759-770.

Lachner M, O'Carroll D, Rea S, Mechtler K, Jenuwein T (2001) Methylation of histone $\mathrm{H} 3$ lysine 9 creates a binding site for HP1 proteins. Nature 410:116-120.

Luthi-Carter R, Strand A, Peters NL, Solano SM, Hollingsworth ZR, Menon AS, Frey AS, Spektor BS, Penney EB, Schilling G, Ross CA, Borchelt DR, Tapscott SJ, Young AB, Cha JH, Olson JM (2000) Decreased expression of striatal signaling genes in a mouse model of Huntington's disease. Hum Mol Genet 9:1259-1271.

Mangiarini L, Sathasivam K, Seller M, Cozens B, Harper A, Hetherington C, Lawton M, Trottier Y, Lehrach H, Davies SW, Bates GP (1996) Exon 1 of the HD gene with an expanded CAG repeat is sufficient to cause a progressive neurological phenotype in transgenic mice. Cell 87:493-506.

McCampbell A, Taye AA, Whitty L, Penney E, Steffan JS, Fischbeck KH (2001) Histone deacetylase inhibitors reduce polyglutamine toxicity. Proc Natl Acad Sci USA 98:15179-15184.

$\mathrm{Ng} \mathrm{HH}$, Xu RM, Zhang Y, Struhl K (2002) Ubiquitination of histone H2B by Rad6 is required for efficient Dot1-mediated methylation of histone H3 lysine 79. J Biol Chem 277:34655-34657.

Ng HH, Robert F, Young RA, Struhl K (2003) Targeted recruitment of Set1 histone methylase by elongating Pol II provides a localized mark and memory of recent transcriptional activity. Mol Cell 11:709-719.

Nickel BE, Davie JR (1989) Structure of polyubiquitinated histone H2A. Biochemistry 28:964-968.

Nickel BE, Allis CD, Davie JR (1989) Ubiquitinated histone H2B is preferentially located in transcriptionally active chromatin. Biochemistry 28:958-963.

Peters AH, Kubicek S, Mechtler K, O’Sullivan RJ, Derijck AA, Perez-Burgos L, Kohlmaier A, Opravil S, Tachibana M, Shinkai Y, Martens JH, Jenuwein T (2003) Partitioning and plasticity of repressive histone methylation states in mammalian chromatin. Mol Cell 12:1577-1589.

Roth SY, Denu JM, Allis CD (2001) Histone acetyltransferases. Annu Rev Biochem 70:81-120.

Ryu H, Ferrante RJ (2005) Emerging chemotherapeutic strategies for Huntington's disease. Expert Opin Emerg Drugs 10:345-363.
Ryu H, Lee J, Hagerty SW, Soh BY, McAlpin SE, Cormier KA, Smith KM, Ferrante RJ (2006) ESET/SETDB1 gene expression and histone H3 (K9) trimethylation in Huntington's disease. Proc Natl Acad Sci USA 103:19176-19181.

Sadri-Vakili G, Bouzou B, Benn CL, Kim MO, Chawla P, Overland RP, Glajch KE, Xia E, Qiu Z, Hersch SM, Clark TW, Yohrling GJ, Cha JH (2007) Histones associated with downregulated genes are hypo-acetylated in Huntington's disease models. Hum Mol Genet 16:1293-1306.

Santos-Rosa H, Schneider R, Bannister AJ, Sherriff J, Bernstein BE, Emre NC, Schreiber SL, Mellor J, Kouzarides T (2002) Active genes are trimethylated at K4 of histone H3. Nature 419:407-411.

Schotta G, Ebert A, Krauss V, Fischer A, Hoffmann J, Rea S, Jenuwein T, Dorn R, Reuter G (2002) Central role of Drosophila SU(VAR)3-9 in histone $\mathrm{H} 3-\mathrm{K} 9$ methylation and heterochromatic gene silencing. EMBO J 21:1121-1131.

Shahbazian MD, Zhang K, Grunstein M (2005) Histone H2B ubiquitylation controls processive methylation but not monomethylation by Dot1 and Set1. Mol Cell 19:271-277.

Shiio Y, Eisenman RN (2003) Histone sumoylation is associated with transcriptional repression. Proc Natl Acad Sci USA 100:13225-13230.

Sipione S, Rigamonti D, Valenza M, Zuccato C, Conti L, Pritchard J, Kooperberg C, Olson JM, Cattaneo E (2002) Early transcriptional profiles in huntingtin-inducible striatal cells by microarray analyses. Hum Mol Genet 11:1953-1965.

Stack EC, Del Signore SJ, Luthi-Carter R, Soh BY, Goldstein DR, Matson S, Goodrich S, Markey AL, Cormier K, Hagerty SW, Smith K, Ryu H, Ferrante RJ (2007) Modulation of nucleosome dynamics in Huntington's disease. Hum Mol Genet 16:1164-1175.

Steffan JS, Bodai L, Pallos J, Poelman M, McCampbell A, Apostol BL, Kazantsev A, Schmidt E, Zhu YZ, Greenwald M, Kurokawa R, Housman DE, Jackson GR, Marsh JL, Thompson LM (2001) Histone deacetylase inhibitors arrest polyglutamine-dependent neurodegeneration in Drosophila. Nature 413:739-743.

Strahl BD, Allis CD (2000) The language of covalent histone modifications. Nature 403:41-45.

Sun ZW, Allis CD (2002) Ubiquitination of histone H2B regulates H3 methylation and gene silencing in yeast. Nature 418:104-108.

The Huntington's Disease Collaborative Research Group (1993) A novel gene containing a trinucleotide repeat that is expanded and unstable on Huntington's disease chromosomes. Cell 72:971-983.

Thorne AW, Sautiere P, Briand G, Crane-Robinson C (1987) The structure of ubiquitinated histone H2B. EMBO J 6:1005-1010.

Trettel F, Rigamonti D, Hilditch-Maguire P, Wheeler VC, Sharp AH, Persichetti F, Cattaneo E, MacDonald ME (2000) Dominant phenotypes produced by the HD mutation in STHdh(Q111) striatal cells. Hum Mol Genet 9:2799-2809.

Valera AG, Diaz-Hernandez M, Hernandez F, Ortega Z, Lucas JJ (2005) The ubiquitin-proteasome system in Huntington's disease. Neuroscientist 11:583-594.

van der Knaap JA, Kumar BR, Moshkin YM, Langenberg K, Krijgsveld J, Heck AJ, Karch F, Verrijzer CP (2005) GMP synthetase stimulates histone H2B deubiquitylation by the epigenetic silencer USP7. Mol Cell 17:695-707.

Wang H, Wang L, Erdjument-Bromage H, Vidal M, Tempst P, Jones RS, Zhang Y (2004) Role of histone H2A ubiquitination in Polycomb silencing. Nature 431:873-878.

West MH, Bonner WM (1980) Histone 2B can be modified by the attachment of ubiquitin. Nucleic Acids Res 8:4671-4680.

Yohrling GJ, Farrell LA, Hollenberg AN, Cha JH (2003) Mutant huntingtin increases nuclear corepressor function and enhances ligand-dependent nuclear hormone receptor activation. Mol Cell Neurosci 23:28-38.

Zhu B, Zheng Y, Pham AD, Mandal SS, Erdjument-Bromage H, Tempst P, Reinberg D (2005) Monoubiquitination of human histone H2B: the factors involved and their roles in HOX gene regulation. Mol Cell 20:601611. 